Review

\title{
Lipid Disorders in NAFLD and Chronic Kidney Disease
}

\author{
Meng Yang ${ }^{1,2}$, Chang-An Geng ${ }^{3}$, Xinguang Liu ${ }^{1, *} \mathbb{1}$ and Min Guan ${ }^{2, *} \mathbb{C}$ \\ 1 Guangdong Provincial Key Laboratory of Medical Molecular Diagnostics, Institute of Biochemistry and \\ Molecular Biology, Institute of Aging Research, Guangdong Medical University, Dongguan 523808, China; \\ yangmeng@gdmu.edu.cn \\ 2 Center for Human Tissues and Organs Degeneration, Institute of Biomedicine and Biotechnology, Shenzhen \\ Institute of Advanced Technology, Chinese Academy of Sciences, Shenzhen 518055, China \\ 3 State Key Laboratory of Phytochemistry and Plant Resources in West China, Kunming Institute of Botany, \\ Chinese Academy of Sciences, Kunming 650201, China; gengchangan@mail.kib.ac.cn \\ * Correspondence: xgliu@gdmu.edu.cn (X.L.); min.guan@siat.ac.cn (M.G.); Tel.: +86-755-86585232 (M.G.)
}

check for updates

Citation: Yang, M.; Geng, C.-A.; Liu, X.; Guan, M. Lipid Disorders in NAFLD and Chronic Kidney Disease. Biomedicines 2021, 9, 1405. https:// doi.org/10.3390/biomedicines9101405

Academic Editor: Henricus A.

M. Mutsaers

Received: 26 August 2021

Accepted: 30 September 2021

Published: 6 October 2021

Publisher's Note: MDPI stays neutral with regard to jurisdictional claims in published maps and institutional affiliations.

Copyright: (C) 2021 by the authors. Licensee MDPI, Basel, Switzerland. This article is an open access article distributed under the terms and conditions of the Creative Commons Attribution (CC BY) license (https:/ / creativecommons.org/licenses/by/ $4.0 /)$.
Abstract: Nonalcoholic fatty liver disease (NAFLD) is the most common cause of chronic liver dysfunction and is characterized by exaggerated lipid accumulation, inflammation and even fibrosis. It has been shown that NAFLD increases the risk of other chronic diseases, particularly chronic kidney disease (CKD). Lipid in excess could lead to liver and kidney lesions and even end-stage disease through diverse pathways. Dysregulation of lipid uptake, oxidation or de novo lipogenesis contributes to the toxic effects of ectopic lipids which promotes the development and progression of NAFLD and CKD via triggering oxidative stress, apoptosis, pro-inflammatory and profibrotic responses. Importantly, dyslipidemia and release of pro-inflammatory cytokines caused by NAFLD (specifically, nonalcoholic steatohepatitis) are considered to play important roles in the pathological progression of CKD. Growing evidence of similarities between the pathogenic mechanisms of NAFLD and those of CKD has attracted attention and urged researchers to discover their common therapeutic targets. Here, we summarize the current understanding of molecular aberrations underlying the lipid metabolism of NAFLD and CKD and clinical evidence that suggests the relevance of these pathways in humans. This review also highlights the orchestrated inter-organ cross-talk in lipid disorders, as well as therapeutic options and opportunities to counteract NAFLD and CKD.

Keywords: lipid; NAFLD; chronic kidney disease

\section{Introduction}

Nonalcoholic fatty liver disease (NAFLD) has replaced viral liver diseases as the leading cause of chronic liver disease, with a worldwide prevalence of 25\% [1]. NAFLD is characterized by excessive fat accumulation in hepatocytes and may progress to nonalcoholic steatohepatitis (NASH), ultimately leading to advanced fibrosis and cirrhosis [2]. Hepatic steatosis adversely affects multiple organs, placing abnormal lipid metabolism associated with NAFLD in close relation to many of the current life-style-related diseases [3]. It has been shown that NAFLD is part of a multisystem disease and is considered as a risk factor for extra-hepatic chronic complications, including type 2 diabetes mellitus (T2DM), cardiovascular disease (CVD) and chronic kidney disease (CKD) [4]. CKD is defined by abnormalities of kidney structure or function which are assessed using a matrix of variables including glomerular filtration rate, thresholds of albuminuria and duration of injury [5]. The prevalence of CKD is estimated to be $8-16 \%$ worldwide [6] and it increases to 23.4-35.8\% in patients over 64 years old [7]. Patients with CKD are likely to die prematurely before progressing to end-stage renal disease (ESRD) [8]. The leading cause of death in these patients is CVD, which might be induced by dyslipidemia, hypertension, diabetes mellitus, or other factors [9].

Due to the rise in global epidemics of obesity and T2DM, the incidences of NAFLD and CKD have rapidly grown during recent decades [10]. Recently, increasing attention has 
been focused on NAFLD-related CKD. Emerging data have highlighted a strong correlation between NAFLD and CKD. NAFLD patients are more likely to have a higher urinary albumin excretion rate [11]. A meta-analysis reported that the risk of CKD in NAFLD patients is approximately two-fold higher than non-NAFLD patients [12,13]. Furthermore, NASH and advanced fibrosis are associated with a higher prevalence and incidence of CKD than simple steatosis [12]. Notably, growing evidence has shown that ectopic lipid deposition plays a critical role in accelerating the progression of NAFLD and CKD [14,15]. These clues suggest that NAFLD might be an important risk factor of CKD. As such, a better understanding of NAFLD and CKD pathogenesis regulated by lipid disorder is valuable in the search for novel therapeutic targets for NAFLD and CKD.

Previous reviews indicated that the liver and kidney share a number of pathways that are intrinsically linked to each other and provided an integrated summary of potential mechanisms of NAFLD involvement in CKD [13,16,17]. However, the effects of lipid metabolism in these two diseases are not described in detail. Here, we provide some putative molecular mechanisms of lipid accumulation in the liver and kidney and the pathogenesis of NAFLD and CKD deriving from toxic effects of excess lipids. We further emphasize the current understanding of inter-organ cross-talk between the liver and kidney in lipid metabolism. Finally, we summarize several promising therapies for prevention and treatment of NAFLD and CKD.

\section{Molecular Mechanisms of Hepatic and Renal Lipid Accumulation}

Numerous studies have demonstrated that dysregulation of lipid homeostasis is strongly associated with fatty liver $[18,19]$. In individuals with NAFLD, hepatic lipid accumulation is a consequence of lipid acquisition exceeding lipid disposal. This arises from the disruption of one or more of four major pathways: circulating lipid uptake, de novo lipogenesis, fatty acid oxidation and export of lipids in very low-density lipoproteins (VLDL). Once uptake/production of lipid breaks the equilibrium with oxidation/export, an unsteady state of liver lipid is progressed [20]. Abnormal renal lipid metabolism has also been described in an abundance of animal models with renal injury [21]. Similar to liver, molecular mechanisms responsible for lipid accumulation in the kidney are also associated with dysregulation of multiple lipid metabolism pathways (Figure 1).

Circulating free fatty acid (FFA) can be generated from the absorption of dietary fat or lipolysis of triglycerides (TG) stored in white adipose tissue. Uptake of circulating FFA is largely dependent on both the concentration of plasma fatty acids and the capacities of membrane-bound fatty acid transport proteins (FATPs), as well as cluster of differentiation 36 (CD36) [22]. It is well known that circulating FFA pool in an obese state is held accountable for the majority of liver lipids in NAFLD [23]. Meanwhile, localization of CD36 on the plasma membrane of hepatocytes and CD36 palmitoylation are markedly increased in the liver of mice with NASH, enhancing the uptake of FFA [24]. However, knockdown of FATP2 or FATP5 in mice reduces the hepatocyte fatty acid uptake and ameliorates hepatic steatosis induced by a high-fat diet (HFD) $[25,26]$. Given the high volume of blood that passes through, the kidney is also easily affected by the amount of circulating FFA from lipolysis in adipocytes [27]. In vivo data suggest that FATP2 regulates proximal tubule apical non-esterified fatty acids (NEFA) uptake and could be the crucial inciting factor for kidney fibrosis development [28,29]. Besides, CD36 knockout mice fed an HFD displayed lower renal lipid accumulation and had less glomerular and tubulointerstitial macrophage accumulation, foam cell formation, oxidant stress and interstitial fibrosis [30]. These data indicate that excess fatty-acid transport into the liver and kidney is required for NAFLD and CKD.

Together with elevated lipid influx, an increase in de novo lipid synthesis aggravates hepatic lipid accumulation. A stable isotope study demonstrated that $26 \%$ of hepatic lipid content in patients with NAFLD is derived from de novo lipogenesis [31]. Previous studies have demonstrated the important roles of steroyl-CoA response element binding protein-1c (SREBP-1c) and carbohydrate response element-binding protein (ChREBP) in 
the development of hepatic steatosis due to the increase in transcription of enzymes involved in de novo lipogenesis, including acetyl-CoA carboxylase 1 (ACC1), fatty acid synthase (FASN) and stearoyl-CoA desaturase 1 (SCD1) [32,33]. In addition, fructose, a commonly consumed sugar in Western diet, also significantly upregulates the expression of SREBP-1c and other lipogenic enzymes contributing to lipid disorders [34]. Growing evidence supports that lipogenesis-related SREBP-1c and ChREBP transcription factors also contribute to an increase in TG content in cultured tubular cells $[35,36]$. Overexpression of ChREBP significantly drives reactive oxygen species (ROS) production which may cause renal tubular damage [37]. Meanwhile, renal TG accumulation can be prevented in the kidneys of SREBP1c-defienced mice [38]. As noted above, SREBP-1c and ChREBP are necessary for de novo lipogenesis-induced hepatic or renal lipid accumulation.

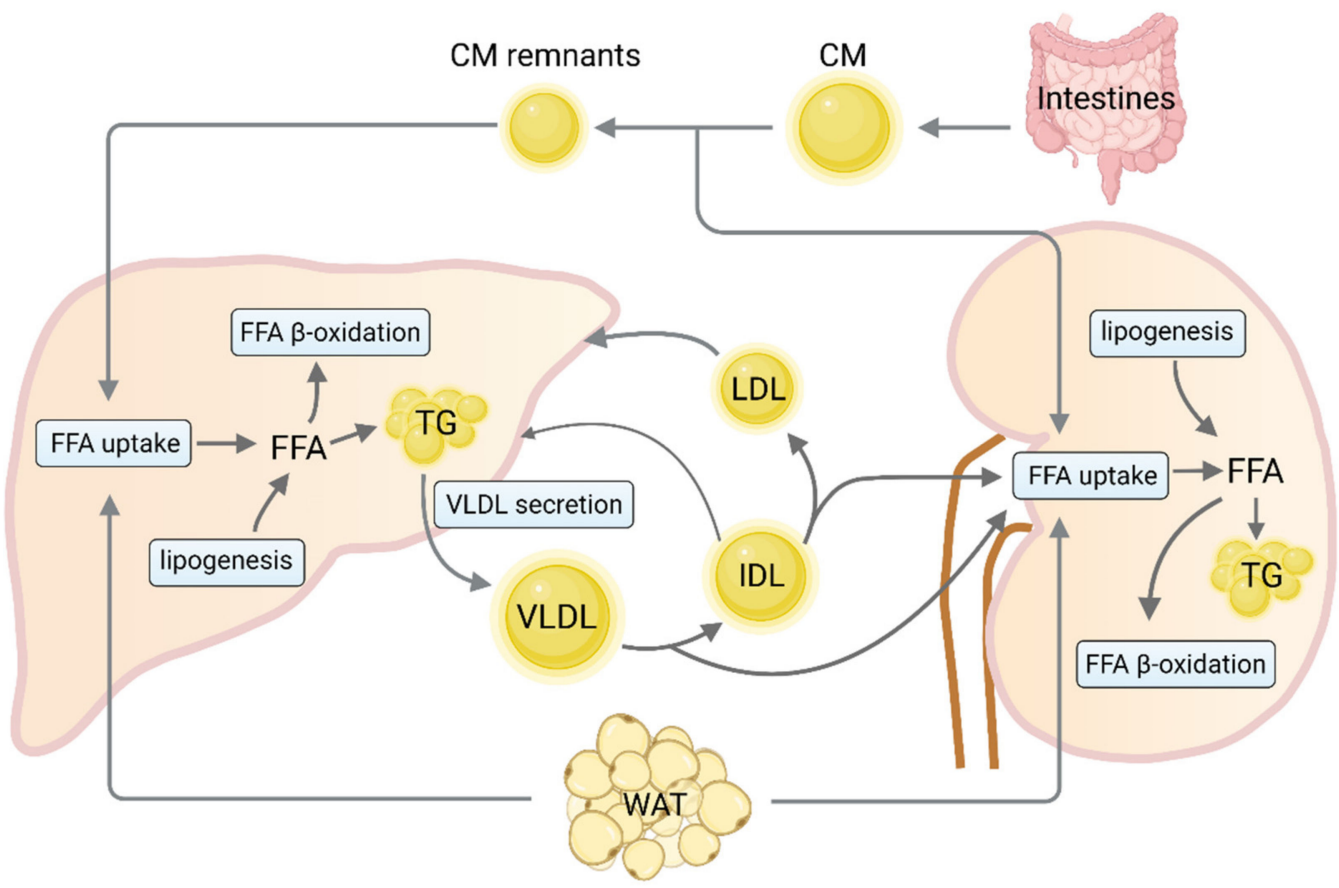

Figure 1. Cross-talk between liver and kidney in lipid metabolism. Dietary fat is incorporated into $\mathrm{CM}$ in the intestine and enters the circulation within two hours after food intake to deliver fatty acids to the kidney before being taken up by the liver as chylomicron remnants. In fasting state, FFA are derived from lipolysis in WAT and are actively taken up by various FA transporters. FFA derived from de novo lipogenesis or circulating are esterified to predominantly produce TG stored within lipid droplets. TG in the liver is packed into VLDL particles and exported into the blood stream for the delivery of fat to the kidney. Alternatively, fatty acids can be oxidized, primarily via $\beta$ oxidation, for energy production in the liver and kidney. This figure was created with BioRender.com (accessed on 2 October 2021). CM, chylomicrons; FFA, free fatty acid; WAT, white adipose tissue; TG, triglycerides; VLDL, very low-density lipoproteins; IDL, intermediate-density lipoprotein; LDL, low-density lipoprotein.

Dysregulated expression of enzymes involved in FFA $\beta$-oxidation also contributes to hepatic and renal lipid accumulation. A liver-specific defect in adipose triglyceride lipase (ATGL) or carnitine palmitoyltransferase 2 (CPT2) results in steatosis and the loss of both components leads to significant steatohepatitis upon high-fat feeding [39]. The activation of peroxisome proliferator-activated receptor $\alpha(\operatorname{PPAR} \alpha)$ induces the transcription of genes related to mitochondrial fatty acid oxidation, such as carnitine palmitoyltransferase $1 \mathrm{~A}$ $(C P T 1 A)$ and acyl-CoA oxidase 1 (ACOX1), thereby reducing lipid accumulation [40]. PPAR $\alpha$ expression is downregulated in patients with NASH and negatively correlates with NASH severity [41]. Furthermore, PPAR $\delta$ also attenuates hepatic steatosis by stimulating autophagy-mediated fatty acid oxidation [42]. In vitro experiments indicated that the 
inhibition of fatty acid oxidation by CPT1 inhibitor etomoxir in proximal tubular cells led to ATP depletion, cell death, dedifferentiation and intracellular lipid deposition, all of which are phenotypes observed in fibrosis [43]. Additionally, aging has been found to aggravate renal lipid accumulation and fibrosis by impairment of PPAR $\alpha$ and the fatty acid oxidation pathway [44]. A longitudinal study that included 92 American Indians with T2DM with preserved glomerular filtration rate suggested impaired fatty acid $\beta$-oxidation may contribute to the progression of diabetic kidney disease [45]. More importantly, genome-wide transcript data from a large cohort of kidney samples from individuals with CKD confirmed the strong enrichment for fatty acid $\beta$-oxidation among the differently expressed pathways [43]. Hence, PPARs are considered as potential therapeutic targets that alleviate intracellular lipids accumulation via enhancing lipid oxidation.

Apart from mitochondrial $\beta$-oxidation, the other major fate of fatty acids in hepatocytes is re-esterification to form TG, which can be exported into the blood as a VLDL particle. The secretion of TG-enriched VLDL (VLDL-TG) from the liver plays an essential role in regulating intrahepatic and circulating lipid homeostasis [46]. Impaired VLDL assembly and secretion is a key factor for developing hepatic steatosis and NASH pathogenesis $[47,48]$. The suppression of hepatic expression of apolipoprotein B (ApoB) and microsomal triglyceride transfer protein (MTP) required for VLDL biogenesis leads to limiting VLDL-TG export and increased hepatic TG accumulation [49]. Cell death-inducing DFF45 like effector B (CIDEB) [50] and phospholipase A2 group XIIB (PLA2G12B) [51,52] also play critical roles in modulating hepatic VLDL-TG secretion and lipid homeostasis. Dysregulation of VLDL-TG secretion has been demonstrated to cause atherogenic dyslipidemia and renal lipid accumulation [53-55]. However, whether hepatic VLDL-TG secretion is associated with the pathogenic progression of CKD remains to be further investigated.

Taken together, lipidosis in liver and kidney is a consequence of an imbalance between the influx of fatty acids, lipid synthesis, oxidation and export, which has been implicated in the pathogenesis of NAFLD and CKD.

\section{Lipid Disorders Contribute to Pathogenic "Cross-Talk" between NAFLD and CKD}

Experimental and epidemiological data reveal some pathophysiological links between them and support the assertion that NAFLD may be a pathogenic factor of CKD [12,13], wherein CKD accelerates the progression of NAFLD [56]. Among these, several mechanisms of action by which lipids can cause liver and renal damage have been proposed. It has been generally accepted that the generation of lipotoxic metabolites of fatty acids typically occurred in parallel with lipid accumulation, which plays a critical role in the pathogenesis of NAFLD and CKD. Lipotoxicity predisposes liver to excessive ROS production $[57,58]$ and oxidative stress which may cause membrane lipid peroxidation, cell necrosis and cell death by apoptosis $[59,60]$. It has been suggested that alterations in the lipid metabolism significantly alter mitochondrial functions in the context of diabetic kidney disease [61], as well as in patients and animal models of NAFLD [62,63]. For example, mitochondrial dysfunction leads to a systemic inflammatory response due to liver injury [63]. The pathogenesis of NAFLD seems to be a vicious cycle of steatosis, lipotoxicity and inflammation resulting in a gradual decline of the biological functions of the liver [64]. Specifically, an overload of FFA into mitochondria may contribute to an increase in the permeability of the inner mitochondrial membrane, which leads to the loss of membrane potential and ATP synthesis capacity, resulting in mitochondrial dysfunction [65]. The initial mitochondrial function impairment can be further amplified by the production of mtDNA mutation by ROS [65]. ROS are important mediators of lipotoxicity-induced injury of visceral glomerular epithelial cells that are essential for maintaining the glomerular tuft and filtration barrier [66]. Moreover, ROS may promote the expression of profibrotic molecules, such as transforming growth factor-beta 1 (TGF- $\beta 1$ ), therefore playing a major role in the development of renal fibrosis, a progressive and usually irreversible process, causing CKD [67]. 
Recent evidence shows that endoplasmic reticulum (ER) stress induced by lipid overload has been widely involved to drive NAFLD progression, as well as kidney injury [68,69]. Activation of the unfolded protein response (UPR) was observed in the livers of experimental obese models, as well as obese humans with NASH [70,71]. ER stress also induces proinflammatory signaling in hepatocytes, thus contributing to inflammation-mediated liver injury in chronic liver diseases [72] and in renal culture cells [73]. Treatment with saturated fatty acid and palmitic acid activated UPR by upregulation of the ER chaperone binding immunoglobulin protein (BIP), transcription factor 4 (ATF4) and proapoptotic transcription factor $\mathrm{C} / \mathrm{EBP}$ homologous protein $(\mathrm{CHOP})$, protein in cultured human proximal tubule epithelial cells [74]. Prolonged ER stress resulted in enhanced apoptosis of lipidenriched proximal tubule cells with colocalization of BIP and SREBP-2 [75]. In addition, ER stress has been causally linked to the development of renal insulin resistance through c-jun N-terminal kinase (JNK) activation and inflammation [76]. A study performed in cultured human glomerular mesangial cells has shown that the inhibition of ER stress by 4-phenylbutyrate markedly suppressed inflammatory cytokine secretion [77]. Based on the mechanistic view described above, mitochondrial dysfunction, ER stress and ROS resulting from intracellular lipid overload play an important role in development of NAFLD, as well as CKD.

On the other hand, lipid metabolism dysfunction is associated with insulin resistance that is considered as a key pathogenic factor in NAFLD and CKD. There is evidence that increased levels of serum FFA, elevated pro-inflammatory cytokines, lower adiponectin levels or an increase in de novo lipogenesis in patients with NAFLD play a central role in mediating insulin resistance [78]. Furthermore, an excess of intrahepatic molecules, such as diacylglycerols (DAGs) and ceramides, are shown to promote hepatic insulin resistance, activate hepatic stellate cells and increase the production of the collagen matrix leading to the progression of liver disease [17]. Meanwhile, HFD or palmitic acid overload leads to the upregulation of inflammation, fibrosis, or cell death in kidneys $[79,80]$. Specifically, treatment with palmitic acid promotes insulin resistance and changes in the cytoskeleton, leading to apoptosis in cultured podocytes [81]. Furthermore, clinical data support that preserved insulin signaling in the glomerular podocyte is an important contributor to normal kidney function [82]. However, disturbance of insulin signaling was observed in individuals with mild, advanced, or end-stage CKD and may directly contribute to the development of diabetic kidney disease [82,83].

Hepatic lipid accumulation in NAFLD induces dyslipidemia by increasing the secretion rate of VLDL [49] and then impacts extrahepatic tissues. VLDL exchanges TG with the cholesterol contained in circulating low-density lipoprotein (LDL) and high-density lipoprotein (HDL), resulting in the formation of small LDL (sLDL) and reduced level of small HDL cholesterol (HDL-C) particles [84]. Coincidentally, dyslipidemia, in the majority of CKD patients, is usually characterized by high LDL cholesterol (LDL-C), low HDL-C and high TG levels [85,86]. LDL levels strongly correlated with lipid contents and fibrosis in grafted kidneys of patients with CKD [87]. The accumulation of oxidized sLDL particles causes renal damage by triggering glomerular injury, mesangial cell proliferation and foam cell formation $[56,88]$. Furthermore, clinical and experiment data have shown that low HDL-C levels were a risk factor for the development of renal dysfunction [89,90]. HDL possesses key antioxidant and anti-inflammatory properties which play a crucial role in the protection against foam cell formation by preventing oxidation of LDL and activation of leukocyte and endothelial cells [91,92]. Significantly lower HDL levels in NAFLD, especially NASH patients [93], may act as a driver of CKD [91]. Additionally, uric acid, ROS and toxic metabolites derived from NAFLD also play crucial roles in the development of CKD [17].

Moreover, liver-specific effects on extrahepatic complications could be mediated by secretion of multiple inflammatory cytokines, such as C-reactive protein (CRP), tumor necrosis factor alpha (TNF- $\alpha$ ) and interleukin 6 (IL-6), or hepatokines, such as fetuin-A, fibroblast growth factor 21 (FGF21) and insulin-like growth factor 1 (IGF-1) [13]. Especially, 
inflamed liver modulates whole-body metabolism and inflammation via CRP, TNF- $\alpha$ and IL-6 [56]. Fetuin-A is secreted exclusively by hepatocytes in response to ER stress [94] and suppresses adiponectin release by adipocytes [95]. Of note, adiponectin was shown to attenuate renal injury and fibrosis in a mouse model of CKD [96]. FGF21 has been demonstrated to attenuate kidney injury in CKD [56,97]. However, there is an impaired action of FGF21 in NAFLD, although its systemic levels are elevated [98]. Additionally, IGF-1 levels are inversely related to the severity of liver injury and crucial for podocyte cell function, thereby maintaining glomerular filtration rate in CKD patients [99]. These effects suggest that NAFLD affects renal injury mainly through lipoprotein dysmetabolism and altered secretion of hepatokines.

Accumulating clinical evidence in recent years indicated an increased risk of NAFLD in CKD patients $[100,101]$. Kidney dysfunction affects NAFLD/NASH pathogenesis mainly through ROS, systemic inflammation, modulating gut microbiota and uremic toxins, as well as renin-angiotensin system (RAS). Above all, gut microbiota modulates the severity of chronic liver damage [102]. The alterations in the composition and function of gut microbiota during the progression of CKD induce leakage of endotoxins, leading to the activation of receptor-mediated immune cells, release of pro-inflammatory cytokines in the circulation and subsequent inflammation within the liver $[103,104]$. Gut microbiota and intestinal dysbiosis occurring in CKD result in the formation of short-chain fatty acids (SFCAs), which contribute to the development of liver adiposity and hepatic insulin resistance $[105,106]$. Accumulation of uremic toxins in the circulation is a common accompaniment to CKD [107]. Notably, the incubation of primary human hepatocytes with uremic toxins significantly downregulated bile acid uptake transporters and interfered with mitochondria function [107]. Furthermore, both the kidney and liver express RAS constituents, the activation of which plays a key role in the pathogenesis of NAFLD and CKD by elevating insulin resistance, oxidative stress and pro-inflammatory cytokine production [16].

The findings reported above not only provide key insights regarding the underlying mechanism linking lipid abnormalities to NAFLD and CKD progression, but also suggest that lipids mediate the pathogenic "cross-talk" between these two diseases. Figure 2 summarizes the risk factors potentially linking NAFLD and CKD. The complex link between NAFLD and CKD suggests that multi-targeted therapies could help in the complicated context. 


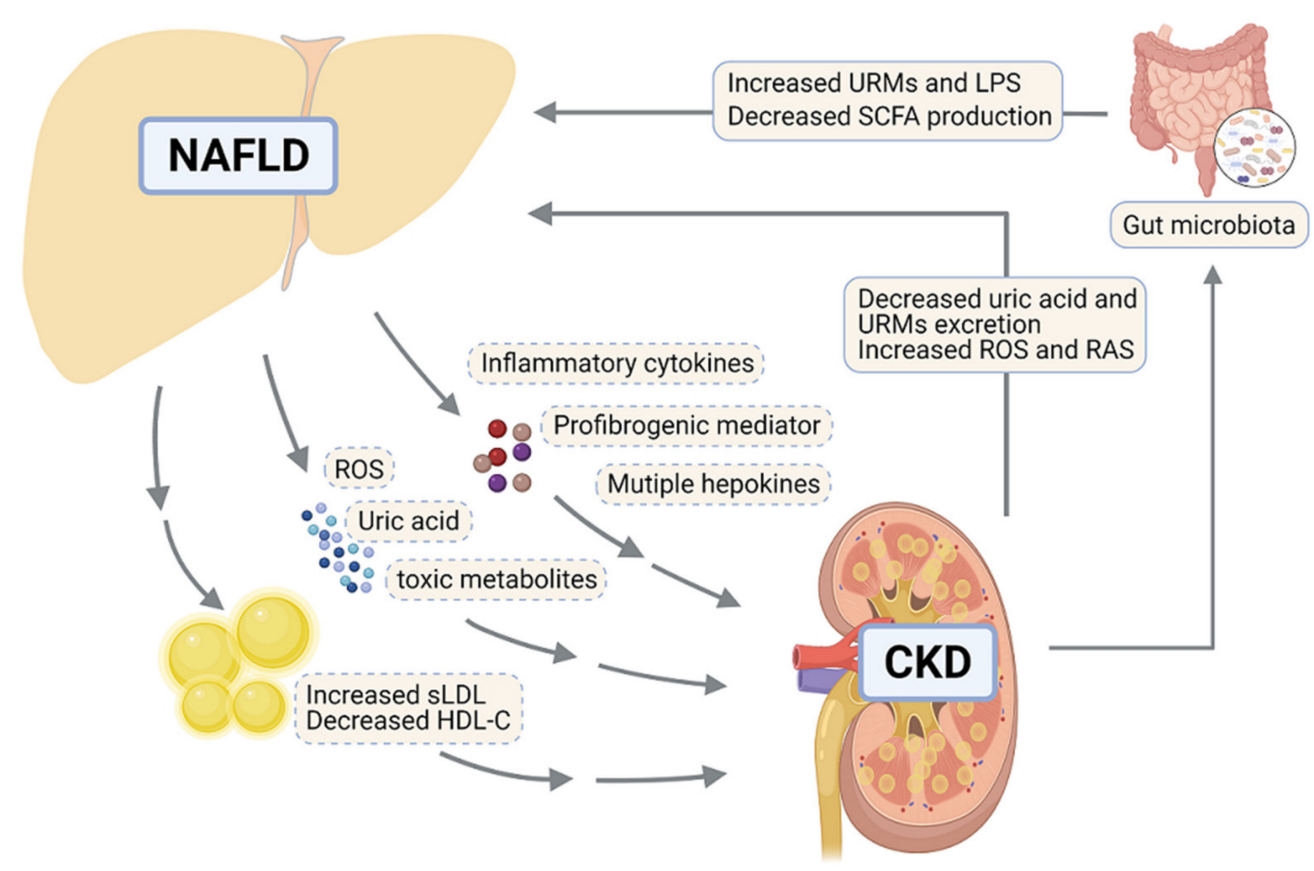

Figure 2. Molecular pathways mediating the interactions between liver and kidney in promoting NAFLD and CKD. In NAFLD, the steatotic and inflamed liver releases inflammatory cytokines including TNF- $\alpha$ and IL-6, profibrogenic mediator and multiple hepatokines (e.g., FGF21), contributing to impaired kidney functions. Additionally, the liver promotes CKD through overproducing uric acid, ROS, certain toxic metabolites and VLDL particles, which promotes atherogenic dyslipidemia through increased SLDL and decreased HDL-C. CKD contributes to NAFLD via reduced excretion of uric acid and URMs, as well as increased ROS and RAS. Furthermore, in CKD, the kidney connects to the pathogenic processes of NAFLD by modulating gut microbiota composition, which enhances the level of URMs, LPS and SCFA. This figure was created with BioRender.com (accessed on 2 October 2021). NAFLD, nonalcoholic fatty liver disease; CKD, chronic kidney disease; sLDL, small low-density lipoprotein; HDL-C, high-density lipoprotein-cholesterol; ROS, reactive oxygen species; RAS, renin-angiotensin system; URMs, uremic retention molecules; LPS, lipopolysaccharide; SCFA, short-chain-fatty acid; TNF- $\alpha$, tumor necrosis factor alpha; IL-6, interleukin 6; FGF21, fibroblast growth factor 21 .

\section{Common Therapeutic Strategies for NAFLD and CKD}

There are currently no approved treatments for NAFLD/NASH, whereas, novel drugs have been approved for CKD [108]. Increasing our knowledge on lipid metabolism in the liver and kidney, as well as their inter-organ cross-talk, could reveal mechanistic insights necessary for the development of new therapeutic strategies for NAFLD/NASH and CKD. Here, we highlight some potential therapeutic targets for the prevention and treatment of NAFLD and CKD (Table 1).

\subsection{Lipid Mediators as Optional Therapeutic Targets}

Sodium-glucose co-transporter-2 (SGLT2) inhibitors appear to represent a promising option for the management of NAFLD and CKD. SGLT2 is expressed almost exclusively in the epithelial cells of the proximal convoluted tubule and mediates approximately $90 \%$ of the active renal glucose reabsorption [109]. SGLT2 inhibitors not only play an important role in improving systemic glucose homeostasis but also have protective effects on the kidney in individuals with T2DM [110]. SGLT2 inhibitors, such as dapagliflozin, empagliflozin and canagliflozin, induce a significant reduction in albuminuria in patients with T2DM and CKD [111]. In a clinical trial setting, canagliflozin treatment in individuals with diabetic kidney disease decreased the levels of inflammation and fibrosis biomarkers, including IL-6, matrix metallopeptidase 7 (MMP7) and fibronectin 1(FN1) [112]. Importantly, 
dapagliflozin is approved in the European Union for treating CKD in adults with and without diabetes [108]. Furthermore, weight loss and increased fatty acid oxidation during the administration of SGLT2 inhibitors could contribute to the reduction of hepatic fat accumulation in patients with T2DM and NAFLD [113]. Empagliflozin could significantly ameliorate liver injury in an animal model of T2DM with NAFLD, through enhancing hepatic macrophage autophagy via the AMP-activated protein kinase/mechanistic target of rapamycin (AMPK/mTOR) signaling pathway and further inhibiting hepatic inflammatory responses [114]. SGLT2 inhibitor NGI001 blocked de novo lipogenesis by substantially suppressing the expression of FASN and SREBP-1c, promoted fatty acid $\beta$-oxidation through increasing the expression of ATGL, CPT1 and PPAR $\alpha$ and thus alleviated fat droplet accumulation in a cell model of human fatty liver [115].

An extensive deregulation of nuclear transcription factors is responsible for lipid abnormalities. It has been revealed that PPARs and farnesoid X nuclear receptor (FXR) are downregulated in NAFLD and CKD [116-119]. PPARs, as members of the steroid hormone receptor superfamily, play key roles in the transcriptional regulation of fatty acid metabolism, inflammation and fibrogenesis [120,121]. On this basis, PPAR ligands are considered as promising therapeutic agents for NAFLD and CKD. For instance, lanifibranor is a pan PPAR agonist that activates all three subtypes $(\alpha, \beta / \delta$ and $\gamma)$, giving it the effectiveness to trigger the resolution of steatohepatitis and regression of fibrosis [116]. A PPAR $\alpha$ agonist, WY14643, seems to prevent tubule cell death and intracellular lipid accumulation [122]. PPAR $\gamma$ agonist rosiglitazone causes the reduction in hepatic steatosis through improving FFA metabolism [123]. As an endogenous ligand of PPAR $\gamma, 15 d-P G J 2$ prevents renal fibrosis in rats undergone unilateral ureteral occlusion surgery leading to renal dysfunction [124]. The activation of FXR locally in the liver has been shown to be protective against the development of hepatic steatosis and NASH via affecting multiple cell types in the liver [125]. FXR agonist obeticholic acid effectively reduced serum TG levels, alanine aminotransferase (ALT) and markers of liver fibrosis in patients with NAFLD and T2DM in a phase II study [126]. Patients with NASH who received obeticholic acid showed improved liver histology (2-point or greater improvement in NAFLD activity score without worsening of fibrosis) [118]. On the other hand, treatment of FXR agonist GW4064 in a type 2 diabetic kidney animal model ameliorated albuminuria, pro-fibrotic and proinflammatory changes, improved renal lipid metabolism and inhibited renal autophagy, apoptosis and ROS production, suggesting that FXR may also be a therapeutic target for CKD $[127,128]$.

Selective thyroid hormone receptor $\beta$ (TR $\beta$ ) agonists also provide new perspectives for the treatment of NAFLD and CKD. The thyroid hormone mediates hepatic lipogenesis, fatty acid $\beta$-oxidation, cholesterol synthesis and reverse cholesterol transport [129]. Treatment with TR $\beta$ agonist resmetirom decreased hepatic steatosis and circulating lipids and repressed fibrogenic genes expression in mice fed a diet high in fat, fructose and cholesterol for 34 weeks [130,131]. A clinicopathological study shows that nephrotic syndrome patients with a thyroid dysfunction have higher urine protein and lipid levels than those with normal thyroid function [132]. TR $\beta$ has also been shown to be expressed in tubule cells of CKD patients and take part in the regulation of cell-cycle progression in renal tubule epithelial cells [133]. These findings support the potential effect of selective TR $\beta$ agonists to improve liver and kidney injury.

Recently, biological agents targeting the proprotein convertase subtilisin-kexin type 9 (PCSK9) have been shown to reduce LDL-C by 50-60\% [134] and alleviate NAFLD [135]. A study indicates that high intrahepatic or circulating PCSK9 levels increase liver lipid storage and secretion, thus contributing to the pathogenesis of NAFLD [136]. PCSK9 inhibitor therapy significantly ameliorates steatosis biomarkers such as the hepatic steatosis index in familial hypercholesterolemia patients with low TG/HDL [137]. In CKD, increased plasma lipid levels are associated with elevated levels of PCSK9, suggesting a role for PCSK9 in CKD-associated dyslipidemia [138]. Given the limited efficacy of statins in CKD, further research could focus on therapeutically targeting PCSK9 to treat CKD. 
Based on their important roles in lipid metabolism, CD36, FATP2 and FGF21 are also considered as potential therapeutic targets for NAFLD and CKD [30,139,140]. Additionally, miRNAs might be molecular targets for metabolic regulation of NAFLD or CKD [141-144], the delivery and application of which require further investigation. Furthermore, studies in the past two years provided novel insights into several promising candidates such as selective peroxisome proliferator-activated receptor alpha modulator (SPPARM $\alpha$ ), 15-lipoxygenase (Alox15) and cAMP-responsive element-binding protein $\mathrm{H}$ (CREBH); it is still necessary to discover more potential molecular targets for the prevention and treatment of NAFLD and CKD.

Table 1. Roles of potential therapeutic targets/strategies in the pathogenesis of NAFLD and CKD.

\begin{tabular}{|c|c|c|c|c|c|}
\hline Targets/Strategies & $\begin{array}{l}\text { Mechanism of } \\
\text { Action }\end{array}$ & Effect on NAFLD & Effect on CKD & Drug Candidates & Ref. \\
\hline SGLT2 & $\begin{array}{l}\text { Mediates renal } \\
\text { glucose } \\
\text { reabsorption }\end{array}$ & $\begin{array}{c}\text { Inhibiting SGLT2 } \\
\text { ameliorates } \\
\text { NAFLD }\end{array}$ & $\begin{array}{l}\text { Inhibiting SGLT2 } \\
\text { ameliorates CKD }\end{array}$ & $\begin{array}{l}\text { Dapagliflozin is } \\
\text { approved for } \\
\text { treating CKD; } \\
\text { Empagliflozin: } \\
\text { Phase } 4 \text { recruiting } \\
\text { (NASH), } \\
\text { NCT04639414 }\end{array}$ & [108-115] \\
\hline PPARs & $\begin{array}{l}\text { Induce fatty acid } \\
\beta \text {-oxidation via } \\
\text { inducing the } \\
\text { transcription of } \\
\text { CPT1A and } \\
\text { ACOX1 } \\
\text { Reduce TG } \\
\text { synthesis and } \\
\text { insulin resistance } \\
\text { Inhibit } \\
\text { inflammatory cell } \\
\text { activation and } \\
\text { fibrotic processes }\end{array}$ & $\begin{array}{c}\text { Improve hepatic } \\
\text { steatosis and } \\
\text { NASH }\end{array}$ & $\begin{array}{l}\text { Prevent renal } \\
\text { fibrosis and } \\
\text { dysfunction }\end{array}$ & $\begin{array}{c}\text { Lanifibranor: } \\
\text { Phase } 2 \text { completed } \\
\text { (NASH), } \\
\text { NCT03008070; } \\
\text { Pioglitazone: } \\
\text { Phase } 2 \text { recruiting } \\
\text { (NASH), } \\
\text { NCT04501406 }\end{array}$ & $\begin{array}{c}{[40,42,117,120-} \\
124,145]\end{array}$ \\
\hline FXR & $\begin{array}{c}\text { Decreases } \\
\text { lipogenesis by } \\
\text { down-regulating } \\
\text { SREBP1c } \\
\text { Regulates bile acid } \\
\text { homeostasis } \\
\text { Enhances insulin } \\
\text { sensitivity } \\
\text { Decreases } \\
\text { autophagy and } \\
\text { apoptosis } \\
\text { Reduces } \\
\text { inflammation and } \\
\text { fibrosis }\end{array}$ & $\begin{array}{c}\text { Protects against } \\
\text { the development } \\
\text { of hepatic steatosis } \\
\text { and NASH }\end{array}$ & $\begin{array}{c}\text { Prevents the } \\
\text { progression of } \\
\text { acute kidney injury } \\
\text { to CKD } \\
\text { Improves diabetic } \\
\text { nephropathy }\end{array}$ & $\begin{array}{c}\text { Obeticholic acid: } \\
\text { Phase } 3 \text { (NASH), } \\
\text { NCT02548351; } \\
\text { Tropifexor: Phase } 2 \\
\text { recruiting (NASH), } \\
\text { NCT04065841; } \\
\text { EYP001a: Phase } 1 \\
\text { completed } \\
\text { (NASH), } \\
\text { NCT03976687 }\end{array}$ & $\begin{array}{l}{[52,118,125-} \\
128,145]\end{array}$ \\
\hline $\mathrm{TR} \beta$ & $\begin{array}{c}\text { Stimulates } \\
\text { expression of } \\
\text { CPT1A and fatty } \\
\text { acid } \beta \text {-oxidation } \\
\text { Decreases } \\
\text { lipogenesis by } \\
\text { attenuating } \\
\text { expression of } \\
\text { SREBP1c } \\
\text { Reduces serum } \\
\text { levels of LDL } \\
\text { cholesterol }\end{array}$ & $\begin{array}{l}\text { Prevents hepatic } \\
\text { steatosis }\end{array}$ & $\begin{array}{l}\text { May prevent cell } \\
\text { death in early } \\
\text { stage of kidney } \\
\text { injury }\end{array}$ & $\begin{array}{c}\text { Resmetirom: Phase } \\
3 \text { recruiting } \\
\text { (NAFLD), } \\
\text { NCT04951219 }\end{array}$ & [129-133,145] \\
\hline
\end{tabular}


Table 1. Cont.

\begin{tabular}{|c|c|c|c|c|c|}
\hline Targets/Strategies & $\begin{array}{l}\text { Mechanism of } \\
\text { Action }\end{array}$ & Effect on NAFLD & Effect on CKD & Drug Candidates & Ref. \\
\hline PCSK9 & $\begin{array}{c}\text { Reduces cell } \\
\text { surface LDL } \\
\text { receptor } \\
\text { concentration and } \\
\text { increases } \\
\text { circulating LDL-C } \\
\text { significantly } \\
\text { Increases VLDL } \\
\text { secretion by } \\
\text { inducing ApoB } \\
\text { and MTTP } \\
\text { expression } \\
\text { Increases insulin } \\
\text { resistance } \\
\text { Increases de novo } \\
\text { lipogenesis by } \\
\text { upregulating } \\
\text { PPAR } \gamma, \text { SREBP1 } \\
\text { and FASN }\end{array}$ & $\begin{array}{l}\text { Induces hepatic } \\
\text { steatosis }\end{array}$ & $\begin{array}{c}\text { Associates with } \\
\text { CKD-related } \\
\text { dyslipidemia }\end{array}$ & $\begin{array}{l}\text { Evolocumab and } \\
\text { Alirocumab are } \\
\text { approved for lipid } \\
\text { lowering therapy }\end{array}$ & {$[134-138,145,146]$} \\
\hline $\begin{array}{l}\text { Modulation of gut } \\
\text { microbiome }\end{array}$ & $\begin{array}{c}\text { Decreases } \\
\text { intracelluar lipid } \\
\text { accumulation, } \\
\text { Reduces } \\
\text { pro-inflammatory } \\
\text { cytokin } \\
\text { Affects bile acid } \\
\text { production } \\
\text { Suppresses the } \\
\text { production of } \\
\text { uremic toxins } \\
\text { Improves urea } \\
\text { utilization }\end{array}$ & $\begin{array}{c}\text { Prevents and } \\
\text { improves NAFLD }\end{array}$ & $\begin{array}{l}\text { Reduces kidney } \\
\text { injury }\end{array}$ & - & [147-158] \\
\hline $\begin{array}{c}\text { MSC } \\
\text { transplantation }\end{array}$ & $\begin{array}{l}\text { Inhibits immune } \\
\text { responses } \\
\text { Decreases cell } \\
\text { apoptosis and } \\
\text { fibrosis } \\
\text { Promotes tissue } \\
\text { regeneration and } \\
\text { regeneration }\end{array}$ & $\begin{array}{l}\text { Improves liver } \\
\text { function and } \\
\text { NASH }\end{array}$ & $\begin{array}{l}\text { Reduces kidney } \\
\text { injury and } \\
\text { promotes } \\
\text { renal repair }\end{array}$ & - & [159-166] \\
\hline
\end{tabular}

\subsection{Novel Therapeutic Strategies}

Lifestyle modifications might help prevent or slow the progression of NAFLD and CKD. Environmental factors such as high fat intake, excessive fructose consumption and vitamin D deficiency can promote the pathogenesis of both NAFLD and CKD [81,167]. It has been proven that all these factors can affect the gut microbiome and impair intestinal immunity $[168,169]$. New therapeutic approaches for modulating gut microbiota have been proposed to prevent and improve NAFLD. Comparisons of germ-free and conventional mice exhibit that gut microbiota prevents fibrosis upon chronic liver injury $[149,156]$. HFD mice that underwent fecal microbiota transplantation for eight weeks presented a noticeable improvement of steatohepatitis via a significant reduction in intrahepatic lipid accumulation and pro-inflammatory cytokines (e.g., Interferon $-\gamma$ and IL-17) [147]. In another study using a mouse model, probiotics treatment protected against the fructose-induced liver steatosis by attenuating Toll-like receptor 4 (TLR4) signaling in the liver $[150,151]$. 
Noteworthy, analyses on clinical data of NAFLD patients show that probiotic mixtures can reduce the levels of ALT and aspartate aminotransferase (AST), reduce liver fat and inflammatory cytokines $[153,154]$. Perturbation of the composition of gut microbiota has also been observed in patients suffering from CKD [157,158]. Although there are few data about fecal microbiota transplantation for the treatment of CKD, interventions designed to restore the imbalance of the gut-kidney symbiosis are possible treatment options. For instance, supplementation with prebiotic lactulose modifies gut microbiota and suppresses the production of uremic toxins, leading to ameliorated renal function in adenine-induced CKD rats [155]. Probiotics also reduce kidney injury by restoring gut microbiota and improving urea utilization $[148,152]$. Therefore, the modulation of the gut microbiome composition may be an effective and safe therapeutic strategy for NAFLD and CKD.

In recent years, mesenchymal stem cells (MSCs)-based therapy has gradually become a hot topic for degenerative and inflammatory disorders, including kidney and liver diseases [162]. The ability of infused MSCs to resolve inflammation and promote renal repair has been demonstrated in various models of kidney diseases. Allogeneic bone marrowderived MSCs (BM-MSCs) transplantation repressed immune responses and induced the remodeling of the extracellular matrix in rats with nephrectomy [163]. Additionally, exosomes derived from BM-MSCs were shown to improve diabetic nephropathy in mice by mediating the attenuation of renal inflammation, cell apoptosis and kidney fibrosis [166]. Adipose tissue-derived MSCs are potent in suppressing inflammation and cellular stress, promoting renal cell survival and ameliorating interstitial fibrosis in pig with renal artery stenosis [164,165]. On the other hand, MSCs therapy has been reported to effectively promote liver regeneration and repair liver injury in NAFLD. MSCs engrafted into the liver restored albumin expression in hepatic parenchymal cells, ameliorated fibrosis and impeded the number of intrahepatic-infiltrating immune cells in a NASH model [159]. MSCs transplantation reduced HFD-induced hepatic steatosis, lobular inflammation and liver fibrosis in mice with NAFLD [161]. BM-MSCs transplantation also alleviated CCl4-induced rat liver fibrosis by suppressing the levels of IL-17A accompanied by the downregulation of the IL6/signal transducer and activator of transcription 3 (STAT3) signaling pathway [160].

\section{Conclusions}

NAFLD and CKD are chronic, frequently progressive conditions that develop in response to sustaining fat accumulation, which is a result of lipid acquisition surpassing lipid disposal. In other words, increased circulating lipid uptake and lipogenesis mediate excessive lipid acquisition in the liver or kidney, while a compensatory enhancement of fatty acid oxidation or VLDL secretion is insufficient in normalizing lipid levels. Enhanced generation of ROS and oxidative stress, as a consequence of lipid overload, represent the primary cause of liver and renal injury. ER stress, mitochondrial dysfunction and insulin resistance further trigger cell apoptosis, inflammation and fibrosis in the liver and kidney. As an important risk factor for CKD, NAFLD can cause renal damage through the induction of atherogenic dyslipidemia and secretion of multiple hepatokines. In return, CKD may affect NAFLD/NASH pathogenesis through gut microbiota and RAS. Accumulating evidence indicates several potential therapeutic targets, including nuclear transcription factors. Moreover, novel therapeutic strategies involving gut microbiota and MSCs may also be promising approaches. In summary, a better understanding of lipid disorder regulated by inter-organ cross-talk between liver and kidney in different disease stages is valuable in the search for novel therapeutic targets for NAFLD and CKD. Nonetheless, the impact of lipid disorder on CKD and NAFLD needs more insights from large-scale prospective studies, paving ways for developing new therapeutic targets.

Author Contributions: Writing—original draft preparation, M.Y.; writing-review and editing, M.G., X.L. and C.-A.G.; supervision, M.G.; funding acquisition, M.G. and X.L. All authors have read and agreed to the published version of the manuscript. 
Funding: This work was funded by the National Key R\&D Program of China, grant number 2018YFA0703100, the National Natural Science Foundation of China, grant numbers 82072493, 81770882, 81570532 and 81971329, Shenzhen Science and Technology Research Funding, grant numbers KQJSCX20180330170052049 and 20170502171625936, and the Guangdong Special Support Program, grant number 2017TQ04R394.

Conflicts of Interest: The authors declare no conflict of interest.

\section{References}

1. Younossi, Z.M.; Golabi, P.; de Avila, L.; Paik, J.M.; Srishord, M.; Fukui, N.; Qiu, Y.; Burns, L.; Afendy, A.; Nader, F. The Global Epidemiology of Nafld and Nash in Patients with Type 2 Diabetes: A Systematic Review and Meta-Analysis. J. Hepatol. 2019, 71, 793-801. [CrossRef]

2. Zhou, J.; Zhou, F.; Wang, W.; Zhang, X.J.; Ji, Y.X.; Zhang, P.; She, Z.G.; Zhu, L.; Cai, J.; Li, H. Epidemiological Features of Nafld from 1999 to 2018 in China. Hepatology 2020, 71, 1851-1864. [CrossRef] [PubMed]

3. Ipsen, D.H.; Lykkesfeldt, J.; Tveden-Nyborg, P. Molecular Mechanisms of Hepatic Lipid Accumulation in Non-Alcoholic Fatty Liver Disease. Cell Mol. Life Sci. 2018, 75, 3313-3327. [CrossRef] [PubMed]

4. Armstrong, M.J.; Adams, L.A.; Canbay, A.; Syn, W.K. Extrahepatic Complications of Nonalcoholic Fatty Liver Disease. Hepatology 2014, 59, 1174-1197. [CrossRef] [PubMed]

5. Glassock, R.J.; Warnock, D.G.; Delanaye, P. The Global Burden of Chronic Kidney Disease: Estimates, Variability and Pitfalls. Nat. Rev. Nephrol. 2017, 13, 104-114. [CrossRef]

6. Jha, V.; Garcia-Garcia, G.; Iseki, K.; Li, Z.; Naicker, S.; Plattner, B.; Saran, R.; Wang, A.Y.; Yang, C.W. Chronic Kidney Disease: Global Dimension and Perspectives. Lancet 2013, 382, 260-272. [CrossRef]

7. Zhong, J.; Yang, H.C.; Fogo, A.B. A Perspective on Chronic Kidney Disease Progression. Am. J. Physiol. Ren. Physiol. 2017, 312, F375-F384. [CrossRef]

8. Webster, A.C.; Nagler, E.V.; Morton, R.L.; Masson, P. Chronic Kidney Disease. Lancet 2017, 389, 1238-1252. [CrossRef]

9. McCullough, K.; Sharma, P.; Ali, T.; Khan, I.; Smith, W.C.; MacLeod, A.; Black, C. Measuring the Population Burden of Chronic Kidney Disease: A Systematic Literature Review of the Estimated Prevalence of Impaired Kidney Function. Nephrol. Dial. Transplant. 2012, 27, 1812-1821. [CrossRef]

10. Monteillet, L.; Gjorgjieva, M.; Silva, M.; Verzieux, V.; Imikirene, L.; Duchampt, A.; Guillou, H.; Mithieux, G.; Rajas, F. Intracellular Lipids Are an Independent Cause of Liver Injury and Chronic Kidney Disease in Non Alcoholic Fatty Liver Disease-Like Context. Mol. Metab. 2018, 16, 100-115. [CrossRef]

11. Li, Y.; Zhu, S.; Li, B.; Shao, X.; Liu, X.; Liu, A.; Wu, B.; Zhang, Y.; Wang, H.; Wang, X.; et al. Association between Non-Alcoholic Fatty Liver Disease and Chronic Kidney Disease in Population with Prediabetes or Diabetes. Int. Urol. Nephrol. 2014, 46, 1785-1791. [CrossRef]

12. Musso, G.; Gambino, R.; Tabibian, J.H.; Ekstedt, M.; Kechagias, S.; Hamaguchi, M.; Hultcrantz, R.; Hagstrom, H.; Yoon, S.K.; Charatcharoenwitthaya, P.; et al. Association of Non-Alcoholic Fatty Liver Disease with Chronic Kidney Disease: A Systematic Review and Meta-Analysis. PLoS Med. 2014, 11, e1001680. [CrossRef] [PubMed]

13. Byrne, C.D.; Targher, G. Nafld: A Multisystem Disease. J. Hepatol. 2015, 62, S47-S64. [CrossRef] [PubMed]

14. Ullah, R.; Rauf, N.; Nabi, G.; Ullah, H.; Shen, Y.; Zhou, Y.D.; Fu, J. Role of Nutrition in the Pathogenesis and Prevention of Non-Alcoholic Fatty Liver Disease: Recent Updates. Int. J. Biol. Sci. 2019, 15, 265-276. [CrossRef] [PubMed]

15. Lee, H.S. Mechanisms and Consequences of Hypertriglyceridemia and Cellular Lipid Accumulation in Chronic Kidney Disease and Metabolic Syndrome. Histol. Histopathol. 2011, 26, 1599-1610.

16. Marcuccilli, M.; Chonchol, M. Nafld and Chronic Kidney Disease. Int. J. Mol. Sci. 2016, 17, 562. [CrossRef] [PubMed]

17. Byrne, C.D.; Targher, G. Nafld as a Driver of Chronic Kidney Disease. J. Hepatol. 2020, 72, 785-801. [CrossRef]

18. Yang, M.; Zhang, M.; Liu, Q.; Xu, T.; Huang, T.; Yao, D.; Wong, C.W.; Liu, J.; Guan, M. 18beta-Glycyrrhetinic Acid Acts through Hepatocyte Nuclear Factor 4 Alpha to Modulate Lipid and Carbohydrate Metabolism. Pharmacol. Res. 2020, 157, 104840. [CrossRef]

19. Zhang, M.; Yang, M.; Wang, N.; Liu, Q.; Wang, B.; Huang, T.; Tong, Y.; Ming, Y.; Wong, C.W.; Liu, J.; et al. Andrographolide Modulates Hnf4alpha Activity Imparting on Hepatic Metabolism. Mol. Cell Endocrinol. 2020, 513, 110867. [CrossRef]

20. Yang, M.; Ma, F.; Guan, M. Role of Steroid Hormones in the Pathogenesis of Nonalcoholic Fatty Liver Disease. Metabolites 2021, 11, 320. [CrossRef] [PubMed]

21. Bobulescu, I.A. Renal Lipid Metabolism and Lipotoxicity. Curr. Opin. Nephrol. Hypertens. 2010, 19, 393-402. [CrossRef] [PubMed]

22. Rada, P.; Gonzalez-Rodriguez, A.; Garcia-Monzon, C.; Valverde, A.M. Understanding Lipotoxicity in Nafld Pathogenesis: Is Cd36 a Key Driver? Cell Death Dis. 2020, 11, 802. [CrossRef]

23. Savage, D.B.; Semple, R.K. Recent Insights into Fatty Liver, Metabolic Dyslipidaemia and Their Links to Insulin Resistance. Curr. Opin. Lipidol. 2010, 21, 329-336. [CrossRef] [PubMed]

24. Zhao, L.; Zhang, C.; Luo, X.; Wang, P.; Zhou, W.; Zhong, S.; Xie, Y.; Jiang, Y.; Yang, P.; Tang, R.; et al. Cd36 Palmitoylation Disrupts Free Fatty Acid Metabolism and Promotes Tissue Inflammation in Non-Alcoholic Steatohepatitis. J. Hepatol. 2018, 69, $705-717$. [CrossRef] [PubMed] 
25. Falcon, A.; Doege, H.; Fluitt, A.; Tsang, B.; Watson, N.; Kay, M.A.; Stahl, A. Fatp2 Is a Hepatic Fatty Acid Transporter and Peroxisomal Very Long-Chain Acyl-Coa Synthetase. Am. J. Physiol. Endocrinol. Metab. 2010, 299, E384-E393. [CrossRef]

26. Doege, H.; Grimm, D.; Falcon, A.; Tsang, B.; Storm, T.A.; Xu, H.; Ortegon, A.M.; Kazantzis, M.; Kay, M.A.; Stahl, A. Silencing of Hepatic Fatty Acid Transporter Protein 5 in Vivo Reverses Diet-Induced Non-Alcoholic Fatty Liver Disease and Improves Hyperglycemia. J. Biol. Chem. 2008, 283, 22186-22192. [CrossRef]

27. Turolo, S.; Edefonti, A.; Syren, M.L.; Marangoni, F.; Morello, W.; Agostoni, C.; Montini, G. Fatty Acids in Nephrotic Syndrome and Chronic Kidney Disease. J. Ren. Nutr. 2018, 28, 145-155. [CrossRef]

28. Khan, S.; Cabral, P.D.; Schilling, W.P.; Schmidt, Z.W.; Uddin, A.N.; Gingras, A.; Madhavan, S.M.; Garvin, J.L.; Schelling, J.R. Kidney Proximal Tubule Lipoapoptosis Is Regulated by Fatty Acid Transporter-2 (Fatp2). J. Am. Soc. Nephrol. 2018, 29 , 81-91. [CrossRef]

29. Chen, Y.; Yan, Q.; Lv, M.; Song, K.; Dai, Y.; Huang, Y.; Zhang, L.; Zhang, C.; Gao, H. Involvement of Fatp2-Mediated Tubular Lipid Metabolic Reprogramming in Renal Fibrogenesis. Cell Death Dis. 2020, 11, 994. [CrossRef] [PubMed]

30. Yang, X.; Okamura, D.M.; Lu, X.; Chen, Y.; Moorhead, J.; Varghese, Z.; Ruan, X.Z. Cd36 in Chronic Kidney Disease: Novel Insights and Therapeutic Opportunities. Nat. Rev. Nephrol. 2017, 13, 769-781. [CrossRef] [PubMed]

31. Donnelly, K.L.; Smith, C.I.; Schwarzenberg, S.J.; Jessurun, J.; Boldt, M.D.; Parks, E.J. Sources of Fatty Acids Stored in Liver and Secreted Via Lipoproteins in Patients with Nonalcoholic Fatty Liver Disease. J. Clin. Investig. 2005, 115, 1343-1351. [CrossRef] [PubMed]

32. Moon, Y.A.; Liang, G.; Xie, X.; Frank-Kamenetsky, M.; Fitzgerald, K.; Koteliansky, V.; Brown, M.S.; Goldstein, J.L.; Horton, J.D. The Scap/Srebp Pathway Is Essential for Developing Diabetic Fatty Liver and Carbohydrate-Induced Hypertriglyceridemia in Animals. Cell Metab. 2012, 15, 240-246. [CrossRef] [PubMed]

33. Dentin, R.; Benhamed, F.; Hainault, I.; Fauveau, V.; Foufelle, F.; Dyck, J.R.; Girard, J.; Postic, C. Liver-Specific Inhibition of Chrebp Improves Hepatic Steatosis and Insulin Resistance in Ob/Ob Mice. Diabetes 2006, 55, 2159-2170. [CrossRef] [PubMed]

34. Softic, S.; Gupta, M.K.; Wang, G.X.; Fujisaka, S.; O’Neill, B.T.; Rao, T.N.; Willoughby, J.; Harbison, C.; Fitzgerald, K.; Ilkayeva, O.; et al. Divergent Effects of Glucose and Fructose on Hepatic Lipogenesis and Insulin Signaling. J. Clin. Investig. 2017, 127, 4059-4074. [CrossRef] [PubMed]

35. Sun, L.; Halaihel, N.; Zhang, W.; Rogers, T.; Levi, M. Role of Sterol Regulatory Element-Binding Protein 1 in Regulation of Renal Lipid Metabolism and Glomerulosclerosis in Diabetes Mellitus. J. Biol. Chem. 2002, 277, 18919-18927. [CrossRef] [PubMed]

36. Proctor, G.; Jiang, T.; Iwahashi, M.; Wang, Z.; Li, J.; Levi, M. Regulation of Renal Fatty Acid and Cholesterol Metabolism, Inflammation, and Fibrosis in Akita and Ove26 Mice with Type 1 Diabetes. Diabetes 2006, 55, 2502-2509. [CrossRef] [PubMed]

37. Suzuki, S.; Yokoyama, A.; Noro, E.; Aoki, S.; Shimizu, K.; Shimada, H.; Sugawara, A. Expression and Pathophysiological Significance of Carbohydrate Response Element Binding Protein (Chrebp) in the Renal Tubules of Diabetic Kidney. Endocr. J. 2020, 67, 335-345. [CrossRef]

38. Jiang, T.; Wang, Z.; Proctor, G.; Moskowitz, S.; Liebman, S.E.; Rogers, T.; Lucia, M.S.; Li, J.; Levi, M. Diet-Induced Obesity in $\mathrm{C} 57 \mathrm{bl} / 6 \mathrm{j}$ Mice Causes Increased Renal Lipid Accumulation and Glomerulosclerosis Via a Sterol Regulatory Element-Binding Protein-1c-Dependent Pathway. J. Biol. Chem. 2005, 280, 32317-32325. [CrossRef] [PubMed]

39. Selen, E.S.; Choi, J.; Wolfgang, M.J. Discordant Hepatic Fatty Acid Oxidation and Triglyceride Hydrolysis Leads to Liver Disease. JCI Insight 2021, 6, e135626. [CrossRef]

40. Kersten, S.; Stienstra, R. The Role and Regulation of the Peroxisome Proliferator Activated Receptor Alpha in Human Liver. Biochimie 2017, 136, 75-84. [CrossRef]

41. Francque, S.; Verrijken, A.; Caron, S.; Prawitt, J.; Paumelle, R.; Derudas, B.; Lefebvre, P.; Taskinen, M.R.; Van Hul, W.; Mertens, I.; et al. Pparalpha Gene Expression Correlates with Severity and Histological Treatment Response in Patients with Non-Alcoholic Steatohepatitis. J. Hepatol. 2015, 63, 164-173. [CrossRef] [PubMed]

42. Tong, L.; Wang, L.; Yao, S.; Jin, L.; Yang, J.; Zhang, Y.; Ning, G.; Zhang, Z. Ppardelta Attenuates Hepatic Steatosis through Autophagy-Mediated Fatty Acid Oxidation. Cell Death Dis. 2019, 10, 197. [CrossRef] [PubMed]

43. Kang, H.M.; Ahn, S.H.; Choi, P.; Ko, Y.A.; Han, S.H.; Chinga, F.; Park, A.S.; Tao, J.; Sharma, K.; Pullman, J.; et al. Defective Fatty Acid Oxidation in Renal Tubular Epithelial Cells Has a Key Role in Kidney Fibrosis Development. Nat. Med. 2015, 21, 37-46. [CrossRef] [PubMed]

44. Chung, K.W.; Lee, E.K.; Lee, M.K.; Oh, G.T.; Yu, B.P.; Chung, H.Y. Impairment of Pparalpha and the Fatty Acid Oxidation Pathway Aggravates Renal Fibrosis During Aging. J. Am. Soc. Nephrol. 2018, 29, 1223-1237. [CrossRef]

45. Afshinnia, F.; Nair, V.; Lin, J.; Rajendiran, T.M.; Soni, T.; Byun, J.; Sharma, K.; Fort, P.E.; Gardner, T.W.; Looker, H.C.; et al. Increased Lipogenesis and Impaired Beta-Oxidation Predict Type 2 Diabetic Kidney Disease Progression in American Indians. JCI Insight 2019, 4, e130317. [CrossRef] [PubMed]

46. Wang, X.; Guo, M.; Wang, Q.; Wang, Q.; Zuo, S.; Zhang, X.; Tong, H.; Chen, J.; Wang, H.; Chen, X.; et al. The Patatin-Like Phospholipase Domain Containing Protein 7 Facilitates Vldl Secretion by Modulating Apoe Stability. Hepatology 2020, 72 , 1569-1585. [CrossRef]

47. Fujita, K.; Nozaki, Y.; Wada, K.; Yoneda, M.; Fujimoto, Y.; Fujitake, M.; Endo, H.; Takahashi, H.; Inamori, M.; Kobayashi, N.; et al. Dysfunctional Very-Low-Density Lipoprotein Synthesis and Release Is a Key Factor in Nonalcoholic Steatohepatitis Pathogenesis. Hepatology 2009, 50, 772-780. [CrossRef] [PubMed] 
48. Shin, J.Y.; Hernandez-Ono, A.; Fedotova, T.; Ostlund, C.; Lee, M.J.; Gibeley, S.B.; Liang, C.C.; Dauer, W.T.; Ginsberg, H.N.; Worman, H.J. Nuclear Envelope-Localized Torsina-Lap1 Complex Regulates Hepatic Vldl Secretion and Steatosis. J. Clin. Investig. 2019, 129, 4885-4900. [CrossRef]

49. Yang, M.; Liu, Q.; Huang, T.; Tan, W.; Qu, L.; Chen, T.; Pan, H.; Chen, L.; Liu, J.; Wong, C.W.; et al. Dysfunction of Estrogen-Related Receptor Alpha-Dependent Hepatic Vldl Secretion Contributes to Sex Disparity in Nafld/Nash Development. Theranostics 2020, 10, 10874-10891. [CrossRef]

50. Ye, J.; Li, J.Z.; Liu, Y.; Li, X.; Yang, T.; Ma, X.; Li, Q.; Yao, Z.; Li, P. Cideb, an Er- and Lipid Droplet-Associated Protein, Mediates Vldl Lipidation and Maturation by Interacting with Apolipoprotein B. Cell Metab. 2009, 9, 177-190. [CrossRef] [PubMed]

51. Guan, M.; Qu, L.; Tan, W.; Chen, L.; Wong, C.W. Hepatocyte Nuclear Factor-4 Alpha Regulates Liver Triglyceride Metabolism in Part through Secreted Phospholipase a(2) Gxiib. Hepatology 2011, 53, 458-466. [CrossRef] [PubMed]

52. Liu, Q.; Yang, M.; Fu, X.; Liu, R.; Sun, C.; Pan, H.; Wong, C.W.; Guan, M. Activation of Farnesoid X Receptor Promotes Triglycerides Lowering by Suppressing Phospholipase A2 G12b Expression. Mol. Cell Endocrinol. 2016, 436, 93-101. [CrossRef]

53. Adiels, M.; Olofsson, S.O.; Taskinen, M.R.; Boren, J. Overproduction of Very Low-Density Lipoproteins Is the Hallmark of the Dyslipidemia in the Metabolic Syndrome. Arterioscler. Thromb. Vasc. Biol. 2008, 28, 1225-1236. [CrossRef]

54. Li, J.; Li, H.; Wen, Y.B.; Li, X.W. Very-Low-Density Lipoprotein-Induced Triglyceride Accumulation in Human Mesangial Cells Is Mainly Mediated by Lipoprotein Lipase. Nephron. Physiol. 2008, 110, p1-p10. [CrossRef]

55. Milutinovic, D.V.; Brkljacic, J.; Teofilovic, A.; Bursac, B.; Nikolic, M.; Gligorovska, L.; Kovacevic, S.; Djordjevic, A.; Preitner, F.; Tappy, L.; et al. Chronic Stress Potentiates High Fructose-Induced Lipogenesis in Rat Liver and Kidney. Mol. Nutr. Food Res. 2020, 64, e1901141. [CrossRef]

56. Musso, G.; Cassader, M.; Cohney, S.; Pinach, S.; Saba, F.; Gambino, R. Emerging Liver-Kidney Interactions in Nonalcoholic Fatty Liver Disease. Trends Mol. Med. 2015, 21, 645-662. [CrossRef] [PubMed]

57. Neuschwander-Tetri, B.A. Hepatic Lipotoxicity and the Pathogenesis of Nonalcoholic Steatohepatitis: The Central Role of Nontriglyceride Fatty Acid Metabolites. Hepatology 2010, 52, 774-788. [CrossRef] [PubMed]

58. Fu, S.; Yang, L.; Li, P.; Hofmann, O.; Dicker, L.; Hide, W.; Lin, X.; Watkins, S.M.; Ivanov, A.R.; Hotamisligil, G.S. Aberrant Lipid Metabolism Disrupts Calcium Homeostasis Causing Liver Endoplasmic Reticulum Stress in Obesity. Nature 2011, 473, 528-531. [CrossRef]

59. Alkhouri, N.; Carter-Kent, C.; Feldstein, A.E. Apoptosis in Nonalcoholic Fatty Liver Disease: Diagnostic and Therapeutic Implications. Expert Rev. Gastroenterol. Hepatol. 2011, 5, 201-212. [CrossRef]

60. Syn, W.K.; Choi, S.S.; Diehl, A.M. Apoptosis and Cytokines in Non-Alcoholic Steatohepatitis. Clin. Liver Dis. 2009, 13, 565-580. [CrossRef] [PubMed]

61. Ducasa, G.M.; Mitrofanova, A.; Fornoni, A. Crosstalk between Lipids and Mitochondria in Diabetic Kidney Disease. Curr. Diabetes Rep. 2019, 19, 144. [CrossRef] [PubMed]

62. Wu, L.; Mo, W.; Feng, J.; Li, J.; Yu, Q.; Li, S.; Zhang, J.; Chen, K.; Ji, J.; Dai, W.; et al. Astaxanthin Attenuates Hepatic Damage and Mitochondrial Dysfunction in Non-Alcoholic Fatty Liver Disease by up-Regulating the Fgf21/Pgc-1alpha Pathway. Br. J. Pharmacol. 2020, 177, 3760-3777. [CrossRef]

63. Ajaz, S.; McPhail, M.J.; Gnudi, L.; Trovato, F.M.; Mujib, S.; Napoli, S.; Carey, I.; Agarwal, K. Mitochondrial Dysfunction as a Mechanistic Biomarker in Patients with Non-Alcoholic Fatty Liver Disease (Nafld). Mitochondrion 2021, 57, 119-130. [CrossRef]

64. Cobbina, E.; Akhlaghi, F. Non-Alcoholic Fatty Liver Disease (Nafld)_Pathogenesis, Classification, and Effect on Drug Metabolizing Enzymes and Transporters. Drug Metab. Rev. 2017, 49, 197-211. [CrossRef] [PubMed]

65. Masarone, M.; Rosato, V.; Dallio, M.; Gravina, A.G.; Aglitti, A.; Loguercio, C.; Federico, A.; Persico, M. Role of Oxidative Stress in Pathophysiology of Nonalcoholic Fatty Liver Disease. Oxidative Med. Cell Longev. 2018, 2018, 9547613. [CrossRef]

66. Nishi, H.; Higashihara, T.; Inagi, R. Lipotoxicity in Kidney, Heart, and Skeletal Muscle Dysfunction. Nutrients 2019, 11, 1664. [CrossRef] [PubMed]

67. Welsh, G.I.; Hale, L.J.; Eremina, V.; Jeansson, M.; Maezawa, Y.; Lennon, R.; Pons, D.A.; Owen, R.J.; Satchell, S.C.; Miles, M.J.; et al. Insulin Signaling to the Glomerular Podocyte Is Critical for Normal Kidney Function. Cell Metab. 2010, 12, 329-340. [CrossRef]

68. Chen, J.H.; Wu, C.H.; Chiang, C.K. Therapeutic Approaches Targeting Proteostasis in Kidney Disease and Fibrosis. Int. J. Mol. Sci. 2021, 22, 8674 .

69. Pagliassotti, M.J. Endoplasmic Reticulum Stress in Nonalcoholic Fatty Liver Disease. Annu. Rev. Nutr. 2012, 32, 17-33. [CrossRef]

70. Lee, S.; Kim, S.; Hwang, S.; Cherrington, N.J.; Ryu, D.Y. Dysregulated Expression of Proteins Associated with Er Stress, Autophagy and Apoptosis in Tissues from Nonalcoholic Fatty Liver Disease. Oncotarget 2017, 8, 63370-63381. [CrossRef]

71. Lebeaupin, C.; Vallee, D.; Hazari, Y.; Hetz, C.; Chevet, E.; Bailly-Maitre, B. Endoplasmic Reticulum Stress Signalling and the Pathogenesis of Non-Alcoholic Fatty Liver Disease. J. Hepatol. 2018, 69, 927-947. [CrossRef]

72. Lebeaupin, C.; Proics, E.; de Bieville, C.H.; Rousseau, D.; Bonnafous, S.; Patouraux, S.; Adam, G.; Lavallard, V.J.; Rovere, C.; Le Thuc, O.; et al. Er Stress Induces Nlrp3 Inflammasome Activation and Hepatocyte Death. Cell Death Dis. 2015, 6, e1879. [CrossRef]

73. Sieber, J.; Lindenmeyer, M.T.; Kampe, K.; Campbell, K.N.; Cohen, C.D.; Hopfer, H.; Mundel, P.; Jehle, A.W. Regulation of Podocyte Survival and Endoplasmic Reticulum Stress by Fatty Acids. Am. J. Physiol. Ren. Physiol. 2010, 299, F821-F829. [CrossRef]

74. Li, C.; Lin, Y.; Luo, R.; Chen, S.; Wang, F.; Zheng, P.; Levi, M.; Yang, T.; Wang, W. Intrarenal Renin-Angiotensin System Mediates Fatty Acid-Induced Er Stress in the Kidney. Am. J. Physiol. Ren. Physiol. 2016, 310, F351-F363. [CrossRef] 
75. Lhotak, S.; Sood, S.; Brimble, E.; Carlisle, R.E.; Colgan, S.M.; Mazzetti, A.; Dickhout, J.G.; Ingram, A.J.; Austin, R.C. Er Stress Contributes to Renal Proximal Tubule Injury by Increasing Srebp-2-Mediated Lipid Accumulation and Apoptotic Cell Death. Am. J. Physiol. Ren. Physiol. 2012, 303, F266-F278. [CrossRef] [PubMed]

76. Cnop, M.; Foufelle, F.; Velloso, L.A. Endoplasmic Reticulum Stress, Obesity and Diabetes. Trends Mol. Med. 2012, 18, 59-68. [CrossRef]

77. Yang, H.; Cui, J.; Shi, J.; Yang, B.; Wang, M.; Wu, D.; Zhang, G.; Liu, W.; Li, Q. Endoplasmic Reticulum Stress Participates in Inflammation-Accelerated, Lipid-Mediated Injury of Human Glomerular Mesangial Cells. Nephrology 2017, 22, $234-242$. [CrossRef] [PubMed]

78. Khan, R.S.; Bril, F.; Cusi, K.; Newsome, P.N. Modulation of Insulin Resistance in Nonalcoholic Fatty Liver Disease. Hepatology 2019, 70, 711-724. [CrossRef] [PubMed]

79. Katsoulieris, E.; Mabley, J.G.; Samai, M.; Sharpe, M.A.; Green, I.C.; Chatterjee, P.K. Lipotoxicity in Renal Proximal Tubular Cells: Relationship between Endoplasmic Reticulum Stress and Oxidative Stress Pathways. Free Radic. Biol. Med. 2010, 48, $1654-1662$. [CrossRef] [PubMed]

80. Soumura, M.; Kume, S.; Isshiki, K.; Takeda, N.; Araki, S.; Tanaka, Y.; Sugimoto, T.; Chin-Kanasaki, M.; Nishio, Y.; Haneda, M.; et al. Oleate and Eicosapentaenoic Acid Attenuate Palmitate-Induced Inflammation and Apoptosis in Renal Proximal Tubular Cell. Biochem. Biophys. Res. Commun. 2010, 402, 265-271. [CrossRef]

81. Martinez-Garcia, C.; Izquierdo-Lahuerta, A.; Vivas, Y.; Velasco, I.; Yeo, T.K.; Chen, S.; Medina-Gomez, G. Renal LipotoxicityAssociated Inflammation and Insulin Resistance Affects Actin Cytoskeleton Organization in Podocytes. PLoS ONE 2015, 10, e0142291. [CrossRef]

82. Mitrofanova, A.; Sosa, M.A.; Fornoni, A. Lipid Mediators of Insulin Signaling in Diabetic Kidney Disease. Am. J. Physiol. Ren. Physiol. 2019, 317, F1241-F1252. [CrossRef]

83. Thomas, S.S.; Zhang, L.; Mitch, W.E. Molecular Mechanisms of Insulin Resistance in Chronic Kidney Disease. Kidney Int. 2015, 88, 1233-1239. [CrossRef]

84. Hirano, T. Pathophysiology of Diabetic Dyslipidemia. J. Atheroscler. Thromb. 2018, 25, 771-782. [CrossRef]

85. Ferro, C.J.; Mark, P.B.; Kanbay, M.; Sarafidis, P.; Heine, G.H.; Rossignol, P.; Massy, Z.A.; Mallamaci, F.; Valdivielso, J.M.; Malyszko, J.; et al. Lipid Management in Patients with Chronic Kidney Disease. Nat. Rev. Nephrol. 2018, 14, 727-749. [CrossRef]

86. Kwan, B.C.; Kronenberg, F.; Beddhu, S.; Cheung, A.K. Lipoprotein Metabolism and Lipid Management in Chronic Kidney Disease. J. Am. Soc. Nephrol. 2007, 18, 1246-1261. [CrossRef] [PubMed]

87. Lin, Y.C.; Wang, J.C.; Wu, M.S.; Lin, Y.F.; Chen, C.R.; Chen, C.Y.; Chen, K.C.; Peng, C.C. Nifedipine Exacerbates Lipogenesis in the Kidney Via Kim-1, Cd36, and Srebp Upregulation: Implications from an Animal Model for Human Study. Int. J. Mol. Sci 2020, 21, 4359. [CrossRef]

88. Gyebi, L.; Soltani, Z.; Reisin, E. Lipid Nephrotoxicity: New Concept for an Old Disease. Curr. Hypertens. Rep. 2012, 14, 177-181. [CrossRef] [PubMed]

89. Muntner, P.; Coresh, J.; Smith, J.C.; Eckfeldt, J.; Klag, M.J. Plasma Lipids and Risk of Developing Renal Dysfunction: The Atherosclerosis Risk in Communities Study. Kidney Int. 2000, 58, 293-301. [CrossRef]

90. Fox, C.S.; Larson, M.G.; Leip, E.P.; Culleton, B.; Wilson, P.W.; Levy, D. Predictors of New-Onset Kidney Disease in a CommunityBased Population. JAMA 2004, 291, 844-850. [CrossRef] [PubMed]

91. Vaziri, N.D.; Norris, K. Lipid Disorders and Their Relevance to Outcomes in Chronic Kidney Disease. Blood Purif. 2011, 31, 189-196. [CrossRef]

92. Barter, P. Lipoprotein Metabolism and Ckd: Overview. Clin. Exp. Nephrol. 2014, 18, 243-246. [CrossRef] [PubMed]

93. Corey, K.E.; Misdraji, J.; Gelrud, L.; Zheng, H.; Chung, R.T.; Krauss, R.M. Nonalcoholic Steatohepatitis Is Associated with an Atherogenic Lipoprotein Subfraction Profile. Lipids Health Dis. 2014, 13, 100. [CrossRef]

94. Heo, J.I.; Yoon, D.W.; Yu, J.H.; Kim, N.H.; Yoo, H.J.; Seo, J.A.; Kim, S.G.; Choi, K.M.; Baik, S.H.; Choi, D.S.; et al. Melatonin Improves Insulin Resistance and Hepatic Steatosis through Attenuation of Alpha-2-Hs-Glycoprotein. J. Pineal Res. 2018, 65, e12493. [CrossRef]

95. Zhao, H.L.; Sui, Y.; Guan, J.; He, L.; Zhu, X.; Fan, R.R.; Xu, G.; Kong, A.P.; Ho, C.S.; Lai, F.M.; et al. Fat Redistribution and Adipocyte Transformation in Uninephrectomized Rats. Kidney Int. 2008, 74, 467-477. [CrossRef] [PubMed]

96. Tian, M.; Tang, L.; Wu, Y.; Beddhu, S.; Huang, Y. Adiponectin Attenuates Kidney Injury and Fibrosis in Deoxycorticosterone Acetate-Salt and Angiotensin Ii-Induced Ckd Mice. Am. J. Physiol. Ren. Physiol. 2018, 315, F558-F571. [CrossRef]

97. Zhang, J.; Li, Y. Fibroblast Growth Factor 21 Analogs for Treating Metabolic Disorders. Front. Endocrinol. 2015, 6, 168. [CrossRef] [PubMed]

98. Yilmaz, Y.; Eren, F.; Yonal, O.; Kurt, R.; Aktas, B.; Celikel, C.A.; Ozdogan, O.; Imeryuz, N.; Kalayci, C.; Avsar, E. Increased Serum Fgf21 Levels in Patients with Nonalcoholic Fatty Liver Disease. Eur. J. Clin. Investig. 2010, 40, 887-892. [CrossRef] [PubMed]

99. Bridgewater, D.J.; Dionne, J.M.; Butt, M.J.; Pin, C.L.; Matsell, D.G. The Role of the Type I Insulin-Like Growth Factor Receptor (Igf-Ir) in Glomerular Integrity. Growth Horm. IGF Res. 2008, 18, 26-37. [CrossRef]

100. Pan, B.; Wan, X.; Ma, M.; Cao, C. Complement C3 and Nonalcoholic Fatty Liver Disease in Chronic Kidney Disease Patients: A Pilot Study. Kidney Blood Press. Res. 2020, 45, 61-69. [CrossRef] [PubMed] 
101. Akahane, T.; Akahane, M.; Namisaki, T.; Kaji, K.; Moriya, K.; Kawaratani, H.; Takaya, H.; Sawada, Y.; Shimozato, N.; Fujinaga, Y.; et al. Association between Non-Alcoholic Fatty Liver Disease and Chronic Kidney Disease: A Cross-Sectional Study. J. Clin. Med. 2020, 9, 1635. [CrossRef] [PubMed]

102. Hu, H.; Lin, A.; Kong, M.; Yao, X.; Yin, M.; Xia, H.; Ma, J.; Liu, H. Intestinal Microbiome and Nafld: Molecular Insights and Therapeutic Perspectives. J. Gastroenterol. 2020, 55, 142-158. [CrossRef]

103. Raj, D.; Tomar, B.; Lahiri, A.; Mulay, S.R. The Gut-Liver-Kidney Axis: Novel Regulator of Fatty Liver Associated Chronic Kidney Disease. Pharmacol. Res. 2020, 152, 104617. [CrossRef] [PubMed]

104. Allison, S.J. Hypertension: Thrombin Amplification Loop in Hypertension. Nat. Rev. Nephrol. 2017, 13, 193. [CrossRef] [PubMed]

105. Bashiardes, S.; Shapiro, H.; Rozin, S.; Shibolet, O.; Elinav, E. Non-Alcoholic Fatty Liver and the Gut Microbiota. Mol. Metab. 2016, 5, 782-794. [CrossRef]

106. Scorletti, E.; Byrne, C.D. Extrahepatic Diseases and Nafld: The Triangular Relationship between Nafld, Type 2-Diabetes and Dysbiosis. Dig. Dis. 2016, 34 (Suppl. S1), 11-18. [CrossRef]

107. Weigand, K.M.; Schirris, T.J.J.; Houweling, M.; van den Heuvel, J.; Koenderink, J.B.; Dankers, A.C.A.; Russel, F.G.M.; Greupink, R. Uremic Solutes Modulate Hepatic Bile Acid Handling and Induce Mitochondrial Toxicity. Toxicol. In Vitro 2019, 56, 52-61. [CrossRef] [PubMed]

108. Forxiga Approved in the Eu for the Treatment of Chronic Kidney Disease in Patients with and without Type-2 Diabetes. Available online: https:/ / bit.ly/31Xr8Bm (accessed on 25 August 2021).

109. Marsenic, O. Glucose Control by the Kidney: An Emerging Target in Diabetes. Am. J. Kidney Dis. 2009, 53, 875-883. [CrossRef] [PubMed]

110. Alicic, R.Z.; Johnson, E.J.; Tuttle, K.R. Sglt2 Inhibition for the Prevention and Treatment of Diabetic Kidney Disease: A Review. Am. J. Kidney Dis. 2018, 72, 267-277. [CrossRef] [PubMed]

111. Kelly, M.S.; Lewis, J.; Huntsberry, A.M.; Dea, L.; Portillo, I. Efficacy and Renal Outcomes of Sglt2 Inhibitors in Patients with Type 2 Diabetes and Chronic Kidney Disease. Postgrad. Med. 2019, 131, 31-42. [CrossRef] [PubMed]

112. Heerspink, H.J.L.; Perco, P.; Mulder, S.; Leierer, J.; Hansen, M.K.; Heinzel, A.; Mayer, G. Canagliflozin Reduces Inflammation and Fibrosis Biomarkers: A Potential Mechanism of Action for Beneficial Effects of Sglt2 Inhibitors in Diabetic Kidney Disease. Diabetologia 2019, 62, 1154-1166. [CrossRef] [PubMed]

113. Kontana, A.; Tziomalos, K. Role of Sodium-Glucose Co-Transporter-2 Inhibitors in the Management of Nonalcoholic Fatty Liver Disease. World J. Gastroenterol. 2019, 25, 3664-3668. [CrossRef] [PubMed]

114. Meng, Z.; Liu, X.; Li, T.; Fang, T.; Cheng, Y.; Han, L.; Sun, B.; Chen, L. The Sglt2 Inhibitor Empagliflozin Negatively Regulates Il-17/Il-23 Axis-Mediated Inflammatory Responses in T2dm with Nafld Via the Ampk/Mtor/Autophagy Pathway. Int. Immunopharmacol. 2021, 94, 107492. [CrossRef] [PubMed]

115. Chiang, H.; Lee, J.C.; Huang, H.C.; Huang, H.; Liu, H.K.; Huang, C. Delayed Intervention with a Novel Sglt2 Inhibitor Ngi001 Suppresses Diet-Induced Metabolic Dysfunction and Non-Alcoholic Fatty Liver Disease in Mice. Br. J. Pharmacol. 2020, 177, 239-253. [CrossRef] [PubMed]

116. Boubia, B.; Poupardin, O.; Barth, M.; Binet, J.; Peralba, P.; Mounier, L.; Jacquier, E.; Gauthier, E.; Lepais, V.; Chatar, M.; et al. Design, Synthesis, and Evaluation of a Novel Series of Indole Sulfonamide Peroxisome Proliferator Activated Receptor (Ppar) Alpha/Gamma/Delta Triple Activators: Discovery of Lanifibranor, a New Antifibrotic Clinical Candidate. J. Med. Chem. 2018, 61, 2246-2265. [CrossRef] [PubMed]

117. Zhou, Y.; Lin, S.; Zhang, L.; Li, Y. Resveratrol Prevents Renal Lipotoxicity in High-Fat Diet-Treated Mouse Model through Regulating Ppar-Alpha Pathway. Mol. Cell Biochem. 2016, 411, 143-150. [CrossRef] [PubMed]

118. Neuschwander-Tetri, B.A.; Loomba, R.; Sanyal, A.J.; Lavine, J.E.; Van Natta, M.L.; Abdelmalek, M.F.; Chalasani, N.; Dasarathy, S.; Diehl, A.M.; Hameed, B.; et al. Farnesoid X Nuclear Receptor Ligand Obeticholic Acid for Non-Cirrhotic, Non-Alcoholic Steatohepatitis (Flint): A Multicentre, Randomised, Placebo-Controlled Trial. Lancet 2015, 385, 956-965. [CrossRef]

119. Musso, G.; Cassader, M.; Cohney, S.; De Michieli, F.; Pinach, S.; Saba, F.; Gambino, R. Fatty Liver and Chronic Kidney Disease: Novel Mechanistic Insights and Therapeutic Opportunities. Diabetes Care 2016, 39, 1830-1845. [CrossRef] [PubMed]

120. Dreyer, C.; Krey, G.; Keller, H.; Givel, F.; Helftenbein, G.; Wahli, W. Control of the Peroxisomal Beta-Oxidation Pathway by a Novel Family of Nuclear Hormone Receptors. Cell 1992, 68, 879-887. [CrossRef]

121. Francque, S.; Szabo, G.; Abdelmalek, M.F.; Byrne, C.D.; Cusi, K.; Dufour, J.F.; Roden, M.; Sacks, F.; Tacke, F. Nonalcoholic Steatohepatitis: The Role of Peroxisome Proliferator-Activated Receptors. Nat. Rev. Gastroenterol. Hepatol. 2021, 18, 24-39. [CrossRef] [PubMed]

122. Sivarajah, A.; Chatterjee, P.K.; Hattori, Y.; Brown, P.A.; Stewart, K.N.; Todorovic, Z.; Mota-Filipe, H.; Thiemermann, C. Agonists of Peroxisome-Proliferator Activated Receptor-Alpha (Clofibrate and Wy14643) Reduce Renal Ischemia/Reperfusion Injury in the Rat. Med. Sci. Monit. 2002, 8, BR532-BR539. [PubMed]

123. Ratziu, V.; Giral, P.; Jacqueminet, S.; Charlotte, F.; Hartemann-Heurtier, A.; Serfaty, L.; Podevin, P.; Lacorte, J.M.; Bernhardt, C.; Bruckert, E.; et al. Rosiglitazone for Nonalcoholic Steatohepatitis: One-Year Results of the Randomized Placebo-Controlled Fatty Liver Improvement with Rosiglitazone Therapy (Flirt) Trial. Gastroenterology 2008, 135, 100-110. [CrossRef] [PubMed]

124. Zhang, Z.H.; He, J.Q.; Zhao, Y.Y.; Chen, H.C.; Tan, N.H. Asiatic Acid Prevents Renal Fibrosis in Uuo Rats Via Promoting the Production of 15d-Pgj2, an Endogenous Ligand of Ppar-Gamma. Acta Pharmacol. Sin. 2020, 41, 373-382. [CrossRef] 
125. Schumacher, J.D.; Guo, G.L. Pharmacologic Modulation of Bile Acid-Fxr-Fgf15/Fgf19 Pathway for the Treatment of Nonalcoholic Steatohepatitis. Handb. Exp. Pharmacol. 2019, 256, 325-357. [PubMed]

126. Mudaliar, S.; Henry, R.R.; Sanyal, A.J.; Morrow, L.; Marschall, H.U.; Kipnes, M.; Adorini, L.; Sciacca, C.I.; Clopton, P.; Castelloe, E.; et al. Efficacy and Safety of the Farnesoid X Receptor Agonist Obeticholic Acid in Patients with Type 2 Diabetes and Nonalcoholic Fatty Liver Disease. Gastroenterology 2013, 145, 574-582.e1. [CrossRef] [PubMed]

127. Kim, D.H.; Park, J.S.; Choi, H.I.; Kim, C.S.; Bae, E.H.; Ma, S.K.; Kim, S.W. The Critical Role of Fxr Is Associated with the Regulation of Autophagy and Apoptosis in the Progression of Aki to Ckd. Cell Death Dis. 2021, 12, 320. [CrossRef]

128. Han, S.Y.; Song, H.K.; Cha, J.J.; Han, J.Y.; Kang, Y.S.; Cha, D.R. Farnesoid X Receptor (Fxr) Agonist Ameliorates Systemic Insulin Resistance, Dysregulation of Lipid Metabolism, and Alterations of Various Organs in a Type 2 Diabetic Kidney Animal Model. Acta Diabetol. 2021, 58, 495-503. [CrossRef] [PubMed]

129. Sinha, R.A.; Singh, B.K.; Yen, P.M. Direct Effects of Thyroid Hormones on Hepatic Lipid Metabolism. Nat. Rev. Endocrinol. 2018, 14, 259-269. [CrossRef]

130. Kannt, A.; Wohlfart, P.; Madsen, A.N.; Veidal, S.S.; Feigh, M.; Schmoll, D. Activation of Thyroid Hormone Receptor-Beta Improved Disease Activity and Metabolism Independent of Body Weight in a Mouse Model of Non-Alcoholic Steatohepatitis and Fibrosis. Br. J. Pharmacol. 2021, 178, 2412-2423. [CrossRef] [PubMed]

131. Harrison, S.A.; Bashir, M.R.; Guy, C.D.; Zhou, R.; Moylan, C.A.; Frias, J.P.; Alkhouri, N.; Bansal, M.B.; Baum, S.; NeuschwanderTetri, B.A.; et al. Resmetirom (Mgl-3196) for the Treatment of Non-Alcoholic Steatohepatitis: A Multicentre, Randomised, Double-Blind, Placebo-Controlled, Phase 2 Trial. Lancet 2019, 394, 2012-2024. [CrossRef]

132. Li, L.Z.; Hu, Y.; Ai, S.L.; Cheng, L.; Liu, J.; Morris, E.; Li, Y.; Gou, S.J.; Fu, P. The Relationship between Thyroid Dysfunction and Nephrotic Syndrome: A Clinicopathological Study. Sci. Rep. 2019, 9, 6421. [CrossRef] [PubMed]

133. Hanai, S.; Uchimura, K.; Takahashi, K.; Ishii, T.; Mitsui, T.; Furuya, F. Hypoxia-Induced Thyroid Hormone Receptor Expression Regulates Cell-Cycle Progression in Renal Tubule Epithelial Cells. Endocr. J. 2021, EJ21-0245. [CrossRef] [PubMed]

134. Cohen, J.C.; Boerwinkle, E.; Mosley, T.H., Jr.; Hobbs, H.H. Sequence Variations in Pcsk9, Low Ldl, and Protection against Coronary Heart Disease. N. Engl. J. Med. 2006, 354, 1264-1272. [CrossRef]

135. Theocharidou, E.; Papademetriou, M.; Reklou, A.; Sachinidis, A.; Boutari, C.; Giouleme, O. The Role of Pcsk9 in the Pathogenesis of Non-Alcoholic Fatty Liver Disease and the Effect of Pcsk9 Inhibitors. Curr. Pharm. Des. 2018, 24, 3654-3657. [CrossRef]

136. Emma, M.R.; Giannitrapani, L.; Cabibi, D.; Porcasi, R.; Pantuso, G.; Augello, G.; Giglio, R.V.; Re, N.L.; Capitano, A.R.; Montalto, G.; et al. Hepatic and Circulating Levels of Pcsk9 in Morbidly Obese Patients: Relation with Severity of Liver Steatosis. Biochim. Biophys. Acta Mol. Cell Biol. Lipids 2020, 1865, 158792. [CrossRef]

137. Scicali, R.; Di Pino, A.; Urbano, F.; Ferrara, V.; Marchisello, S.; Di Mauro, S.; Scamporrino, A.; Filippello, A.; Rabuazzo, A.M.; Purrello, F.; et al. Analysis of Steatosis Biomarkers and Inflammatory Profile after Adding on Pcsk9 Inhibitor Treatment in Familial Hypercholesterolemia Subjects with Nonalcoholic Fatty Liver Disease: A Single Lipid Center Real-World Experience. Nutr. Metab. Cardiovasc. Dis. 2021, 31, 869-879. [CrossRef]

138. Shrestha, P.; van de Sluis, B.; Dullaart, R.P.F.; van den Born, J. Novel Aspects of Pcsk9 and Lipoprotein Receptors in Renal Disease-Related Dyslipidemia. Cell Signal. 2019, 55, 53-64. [CrossRef]

139. Qiu, P.; Wang, H.; Zhang, M.; Zhang, M.; Peng, R.; Zhao, Q.; Liu, J. Fatp2-Targeted Therapies-A Role Beyond Fatty Liver Disease. Pharmacol. Res. 2020, 161, 105228. [CrossRef]

140. Tillman, E.J.; Rolph, T. Fgf21: An Emerging Therapeutic Target for Non-Alcoholic Steatohepatitis and Related Metabolic Diseases. Front. Endocrinol. 2020, 11, 601290. [CrossRef] [PubMed]

141. Esau, C.; Davis, S.; Murray, S.F.; Yu, X.X.; Pandey, S.K.; Pear, M.; Watts, L.; Booten, S.L.; Graham, M.; McKay, R.; et al. Mir-122 Regulation of Lipid Metabolism Revealed by in Vivo Antisense Targeting. Cell Metab. 2006, 3, 87-98. [CrossRef] [PubMed]

142. Weber, G.J.; Purkayastha, B.; Ren, L.; Pushpakumar, S.; Sen, U. Hypertension Exaggerates Renovascular Resistance Via Mir-122Associated Stress Response in Aging. J. Hypertens. 2018, 36, 2226-2236. [CrossRef]

143. Davalos, A.; Goedeke, L.; Smibert, P.; Ramirez, C.M.; Warrier, N.P.; Andreo, U.; Cirera-Salinas, D.; Rayner, K.; Suresh, U.; Pastor-Pareja, J.C.; et al. Mir-33a/B Contribute to the Regulation of Fatty Acid Metabolism and Insulin Signaling. Proc. Natl. Acad. Sci. USA 2011, 108, 9232-9237. [CrossRef] [PubMed]

144. Chau, B.N.; Xin, C.; Hartner, J.; Ren, S.; Castano, A.P.; Linn, G.; Li, J.; Tran, P.T.; Kaimal, V.; Huang, X.; et al. Microrna-21 Promotes Fibrosis of the Kidney by Silencing Metabolic Pathways. Sci. Transl. Med. 2012, 4, 121ra118. [CrossRef]

145. Friedman, S.L.; Neuschwander-Tetri, B.A.; Rinella, M.; Sanyal, A.J. Mechanisms of Nafld Development and Therapeutic Strategies. Nat. Med. 2018, 24, 908-922. [CrossRef] [PubMed]

146. Shafiq, M.; Walmann, T.; Nutalapati, V.; Gibson, C.; Zafar, Y. Effects of Proprotein Convertase Subtilisin/Kexin Type-9 Inhibitors on Fatty Liver. World J. Hepatol. 2020, 12, 1258-1266. [CrossRef]

147. Zhou, D.; Pan, Q.; Shen, F.; Cao, H.X.; Ding, W.J.; Chen, Y.W.; Fan, J.G. Total Fecal Microbiota Transplantation Alleviates High-Fat Diet-Induced Steatohepatitis in Mice Via Beneficial Regulation of Gut Microbiota. Sci. Rep. 2017, 7, 1529. [CrossRef]

148. Simeoni, M.; Citraro, M.L.; Cerantonio, A.; Deodato, F.; Provenzano, M.; Cianfrone, P.; Capria, M.; Corrado, S.; Libri, E.; Comi, A.; et al. An Open-Label, Randomized, Placebo-Controlled Study on the Effectiveness of a Novel Probiotics Administration Protocol (Probiotickd) in Patients with Mild Renal Insufficiency (Stage 3a of Ckd). Eur. J. Nutr. 2019, 58, 2145-2156. [CrossRef]

149. Safari, Z.; Gerard, P. The Links between the Gut Microbiome and Non-Alcoholic Fatty Liver Disease (Nafld). Cell Mol. Life Sci. 2019, 76, 1541-1558. [CrossRef] [PubMed] 
150. Wagnerberger, S.; Spruss, A.; Kanuri, G.; Stahl, C.; Schroder, M.; Vetter, W.; Bischoff, S.C.; Bergheim, I. Lactobacillus Casei Shirota Protects from Fructose-Induced Liver Steatosis: A Mouse Model. J. Nutr. Biochem. 2013, 24, 531-538. [CrossRef]

151. Ma, J.; Zhou, Q.; Li, H. Gut Microbiota and Nonalcoholic Fatty Liver Disease: Insights on Mechanisms and Therapy. Nutrients 2017, 9, 1124. [CrossRef]

152. Plata, C.; Cruz, C.; Cervantes, L.G.; Ramirez, V. The Gut Microbiota and Its Relationship with Chronic Kidney Disease. Int. Urol. Nephrol. 2019, 51, 2209-2226. [CrossRef]

153. Famouri, F.; Shariat, Z.; Hashemipour, M.; Keikha, M.; Kelishadi, R. Effects of Probiotics on Nonalcoholic Fatty Liver Disease in Obese Children and Adolescents. J. Pediatr. Gastroenterol. Nutr. 2017, 64, 413-417. [CrossRef]

154. Sepideh, A.; Karim, P.; Hossein, A.; Leila, R.; Hamdollah, M.; Mohammad, E.G.; Mojtaba, S.; Mohammad, S.; Ghader, G.; Seyed Moayed, A. Effects of Multistrain Probiotic Supplementation on Glycemic and Inflammatory Indices in Patients with Nonalcoholic Fatty Liver Disease: A Double-Blind Randomized Clinical Trial. J. Am. Coll. Nutr. 2016, 35, 500-505. [CrossRef]

155. Sueyoshi, M.; Fukunaga, M.; Mei, M.; Nakajima, A.; Tanaka, G.; Murase, T.; Narita, Y.; Hirata, S.; Kadowaki, D. Effects of Lactulose on Renal Function and Gut Microbiota in Adenine-Induced Chronic Kidney Disease Rats. Clin. Exp. Nephrol. 2019, 23, 908-919. [CrossRef]

156. Mazagova, M.; Wang, L.; Anfora, A.T.; Wissmueller, M.; Lesley, S.A.; Miyamoto, Y.; Eckmann, L.; Dhungana, S.; Pathmasiri, W.; Sumner, S.; et al. Commensal Microbiota Is Hepatoprotective and Prevents Liver Fibrosis in Mice. FASEB J. 2015, 29, 1043-1055. [CrossRef]

157. Kim, S.M.; Song, I.H. The Clinical Impact of Gut Microbiota in Chronic Kidney Disease. Korean J. Intern. Med. 2020, 35, 1305-1316. [CrossRef] [PubMed]

158. Hobby, G.P.; Karaduta, O.; Dusio, G.F.; Singh, M.; Zybailov, B.L.; Arthur, J.M. Chronic Kidney Disease and the Gut Microbiome. Am. J. Physiol. Renal Physiol. 2019, 316, F1211-F1217. [CrossRef]

159. Seki, A.; Sakai, Y.; Komura, T.; Nasti, A.; Yoshida, K.; Higashimoto, M.; Honda, M.; Usui, S.; Takamura, M.; Takamura, T.; et al. Adipose Tissue-Derived Stem Cells as a Regenerative Therapy for a Mouse Steatohepatitis-Induced Cirrhosis Model. Hepatology 2013, 58, 1133-1142. [CrossRef]

160. Farouk, S.; Sabet, S.; Abu Zahra, F.A.; El-Ghor, A.A. Bone Marrow Derived-Mesenchymal Stem Cells Downregulate Il17a Dependent Il6/Stat3 Signaling Pathway in Ccl4-Induced Rat Liver Fibrosis. PLoS ONE 2018, 13, e0206130. [CrossRef] [PubMed]

161. Wang, H.; Wang, D.; Yang, L.; Wang, Y.; Jia, J.; Na, D.; Chen, H.; Luo, Y.; Liu, C. Compact Bone-Derived Mesenchymal Stem Cells Attenuate Nonalcoholic Steatohepatitis in a Mouse Model by Modulation of Cd4 Cells Differentiation. Int. Immunopharmacol. 2017, 42, 67-73. [CrossRef] [PubMed]

162. Shi, Y.; Wang, Y.; Li, Q.; Liu, K.; Hou, J.; Shao, C.; Wang, Y. Immunoregulatory Mechanisms of Mesenchymal Stem and Stromal Cells in Inflammatory Diseases. Nat. Rev. Nephrol. 2018, 14, 493-507. [CrossRef]

163. Nagaishi, K.; Mizue, Y.; Chikenji, T.; Otani, M.; Nakano, M.; Konari, N.; Fujimiya, M. Mesenchymal Stem Cell Therapy Ameliorates Diabetic Nephropathy Via the Paracrine Effect of Renal Trophic Factors Including Exosomes. Sci. Rep. 2016, 6, 34842. [CrossRef] [PubMed]

164. Eirin, A.; Zhu, X.Y.; Puranik, A.S.; Tang, H.; McGurren, K.A.; van Wijnen, A.J.; Lerman, A.; Lerman, L.O. Mesenchymal Stem Cell-Derived Extracellular Vesicles Attenuate Kidney Inflammation. Kidney Int. 2017, 92, 114-124. [CrossRef]

165. Zhu, X.Y.; Urbieta-Caceres, V.; Krier, J.D.; Textor, S.C.; Lerman, A.; Lerman, L.O. Mesenchymal Stem Cells and Endothelial Progenitor Cells Decrease Renal Injury in Experimental Swine Renal Artery Stenosis through Different Mechanisms. Stem Cells 2013, 31, 117-125. [CrossRef] [PubMed]

166. Semedo, P.; Correa-Costa, M.; Antonio Cenedeze, M.; Maria Avancini Costa Malheiros, D.; Antonia dos Reis, M.; Shimizu, M.H.; Seguro, A.C.; Pacheco-Silva, A.; Saraiva Camara, N.O. Mesenchymal Stem Cells Attenuate Renal Fibrosis through Immune Modulation and Remodeling Properties in a Rat Remnant Kidney Model. Stem Cells 2009, 27, 3063-3073. [CrossRef] [PubMed]

167. Jang, C.; Wada, S.; Yang, S.; Gosis, B.; Zeng, X.; Zhang, Z.; Shen, Y.; Lee, G.; Arany, Z.; Rabinowitz, J.D. The Small Intestine Shields the Liver from Fructose-Induced Steatosis. Nat. Metab. 2020, 2, 586-593. [CrossRef] [PubMed]

168. Do, M.H.; Lee, E.; Oh, M.J.; Kim, Y.; Park, H.Y. High-Glucose or -Fructose Diet Cause Changes of the Gut Microbiota and Metabolic Disorders in Mice without Body Weight Change. Nutrients 2018, 10, 761. [CrossRef]

169. Zeng, Y.; Luo, M.; Pan, L.; Chen, Y.; Guo, S.; Luo, D.; Zhu, L.; Liu, Y.; Pan, L.; Xu, S.; et al. Vitamin D Signaling Maintains Intestinal Innate Immunity and Gut Microbiota: Potential Intervention for Metabolic Syndrome and Nafld. Am. J. Physiol. Gastrointest. Liver Physiol. 2020, 318, G542-G553. [CrossRef] 